\title{
Nyelvi menedzselés és nyelvi tanácsadás. Helyzetkép, lehetőségek, feladatok ${ }^{1,2}$
}

\section{Bevezetés}

A nyelvmüveléshez hasonló terminus más európai nyelvközösségekben is ismert, például a csehben jazyková kultura, a szlovákban jazyková kultúra, a németben Sprachkultur (vagy Sprachpflege, 1. pl. Maitz 2010), a svédben språkvård néven (Nekvapil 2008: 251). Az angolban, ahol a nyelvmüvelésnek nincs ilyen nagy hagyománya, a language cultivation kifejezést használják ezek megfelelőjeként (Lanstyák 2014: 20). Figyelembe véve azt, hogy a nyelvmüvelés terminus tartalma koronként és beszélőközösségenként változik, továbbá egyaránt utalhat a szaktudományos nyelvmüvelésre és a laikusok által végzett hétköznapi nyelvmüvelésre (Heltainé Nagy 2007: 20-3; Lanstyák 2014: 9-19), dolgozatomban a nyelvi menedzselés terminust használom a diskurzusok, illetve a nyelvi rendszer megváltoztatására irányuló tevékenységekre, utalva ezzel az általam alkalmazott elméleti keretre, a nyelvmenedzselés-elméletre (Jernudd-Neustupný 1987). Kiindulópontom, hogy az ilyen értelemben vett nyelvmüvelés a többi nyelvtudományi területtel egyenrangú részdiszciplína, amelyet érdemes és szükséges is kutatni, müvelni.

Jernudd és Neustupný (1987: 76) megkülönbözteti a nyelvi menedzselés egyszerü és szervezett válfaját. Míg az előzőt a hétköznapi emberek is végezhetik, az utóbbi tevékenység valamilyen intézményhez kötődik. A szervezett nyelvi menedzselés egyik fontos fajtája a nyelvi tanácsadás, amely a hétköznapi beszélőt többnyire a nyelvhasználat konkrét kérdéseiben igazítja el. Beneš és munkatársai (2018: 122-3) a kérdezők és a nyelvi tanácsadók közti párbeszédet a nyelvi menedzsment körfolyamatába ágyazva értelmezik: a nyelvi problémákat a hétköznapi beszélők észlelik és értékelik (mikromenedzsment), a nyelvészek dolgozzák ki az akciótervet (makromenedzsment), amelyet a beszélök elfogadnak, és (vélhetőleg) végrehajtanak (mikromenedzsment) (vö. Nekvapil 2009: 6).

A dolgozat egyik célja más európai nemzetek nyelvi tanácsadó tevékenységének, ilyen jellegü intézményeinek az összehasonlító bemutatása (2.). A nemzetközi körkép (3.1.-3.7.) mellett részletesen szólok a magyar beszélőközösségben müködő nyelvi tanácsadással foglalkozó intézményekről, nemcsak a magyarországi, hanem a határon túli intézményekre vonatkozóan is (3.8.). A dolgozat utolsó nagy fejezetében (4.) a Nyelvtudományi Intézetben müködő nyelvi tanácsadó szolgálat tevékenységét ismertetem: a részletes történeti összefoglaló mellett a jövőre vonatkozó legfontosabb feladatokat is felvázolom.

1 A tanulmány az EFOP-3.6.1-16-2016-00001 „Kutatási kapacitások és szolgáltatások komplex fejlesztése az Eszterházy Károly Egyetemen” címủ projekt támogatásával készült.

2 Itt fejezem ki köszönetemet azoknak a kollégáknak, akik a dolgozat elkészítésében segítséget nyújtottak. Köszönöm Heltainé Nagy Erzsébetnek és Kemény Gábornak a Nyelvtudományi Intézet nyelvmüvelő munkáját ismertető fejezethez füzött észrevételeiket, pontosításaikat, kiegészítéseiket. A határon túli magyar nyelvi irodákkal kapcsolatos adatokért köszönet illeti Benő Attilát, Csernicskó Istvánt, Lanstyák Istvánt, Misad Katalint, Szoták Szilviát és Vukov Raffai Évát. 


\section{A kutatás előzményei, kérdései}

A nyelvi irodák, tanácsadó szolgálatok helyzete az egyes országokban eltérő lehet, mindezt az adott ország etnikai, társadalmi, kulturális és politikai helyzete, valamint az adott közösség sajátos nyelvi igényei irányítják, és nagymértékben függ az adott ország kodifikációs hagyományaitól, stílusától (Uhlírová 1997: 82). Garvin (1993: 17-9) a kodifikációs stílusokat egy skála mentén képzeli el, amelynek egyik végén az Akadémia által irányított kodifikáció áll. Ebben az esetben a „helyes” nyelvhasználat normáinak érvényesítése a ,jó nyelv” és a „helyes nyelvhasználat” egységes, hivatalos értelmezésén alapul. Tipikusan ilyen kodifikációs stílus jellemzi a klaszszikus Francia Akadémia időszakát vagy - Garvin szerint - a jelenkori Európában a volt szocialista országokat. A kontinuum másik végén a Garvin által szabad vállalkozásnak (free-enterprise) nevezett kodifikációs szokások állnak, például az amerikai angol nyelvterületeken, ahol hivatalos, egységes nyelvi norma nincs, ellenben több nem hivatalos norma létezik, amelyek az egyes helyesírási, nyelvhelyességi kérdésekre eltérő választ adnak. Garvin a kontinuum két végpontja között helyezi el a mai Németország kodifikációs stílusát. A dolgozatban bemutatandó európai országok, nyelvközösségek kiválasztása is ennek a figyelembevételével történt. Azt feltételeztem, hogy azok az országok, ahol akadémiai bázisú (Garvin 1993: 17-8) a kodifikáció (pl. Csehország), illetve valaha az volt (Németország), nagyobb az igény a beszélők körében a nyelvi kérdésekben való szakszerü eligazítás iránt, így valószínüleg lesznek nyelvi tanácsadással foglalkozó intézményei.

Más országok nyelvi menedzselési gyakorlatáról több összefoglaló munka is jelent meg, amely a jelen tanulmány kiindulásaként szolgál. Domínguez és López (1995) összeállította azoknak az intézményeknek a listáját, amelyek szociolingvisztikai, nyelvi tervezési kérdésekkel foglalkoznak - mind az ottani (katalán), mind a nemzetközi színtereken. A szerzők az adatokat főként kérdőív segítségével gyüjtötték, amelyben az intézmény alapadatai (neve, rövidítése, címe, elérhetősége) mellett rákérdeztek annak típusára (pl. kutatóintézet), az intézmény osztályaira, alegységeire, a dolgozók számára, a nyelvi tervezés területeire, a különféle szolgáltatásokra (pl. összefoglaló közlemények, adatbázisok), a közelmúlt főbb publikációira (könyvek, folyóiratok, CD-k stb.), a folyamatban lévő munkákra és a jövőbeni tervekre.

Sándor Klára szerkesztésében jelent meg az az angol nyelvü kötet (Sándor [szerk.] 2000), amely A nyelvi megbélyegzéstöl a nyelvi türelemig (From Stigmatization to Tolerance) címü, 1998 őszétől 1999 öszéig tartó nemzetközi projekt keretein belül készült. A nemzetközi kutatócsoport célja alapvetően az volt, hogy az európai országok nyelvi diszkriminációs sajátosságait egységes szempontokat figyelembe véve összehasonlítsa. Ennek részeként a projektben részt vevő görög, norvég, svéd és magyar kutatók által képviselt országok intézményi háttere is megjelent. E projekt eredményei röviden magyar nyelven is olvashatók, erre a munkára utal tanulmányom 3. fejezetének a címe is: Nyelvmüvelés nálunk és más nemzeteknél (Sándor 2002), és így - áttételesen - Kazinczy közismert müvére is (Ortológus és neológus nálunk és más nemzeteknél).

A Janich és Greule által szerkesztett német nyelvü kézikönyv Európa országainak nyelvmüvelö tevékenységét, intézményeit mutatja be (Janich-Greule [szerk.] 2002). 
Ehhez hasonló magyar nyelvü munka a Balázs Géza és Dede Éva szerkesztésében megjelent kötet (Balázs-Dede [szerk.] 2008), amelynek célja az Európában létező nyelvmüvelö, nyelvi tervezési, nyelvápolási stb. tevékenységek minél szélesebb körü bemutatása - a könyv ezeket egységesen nyelvi kultúráknak nevezi. Ez a kötet és a korábban említettek szolgálnak dolgozatom kiindulópontjául, ám a megjelenésük óta eltelt idő miatt a bennük szereplő adatok aktualizálásra szorulnak, továbbá vizsgálatom fő tárgyára, a nyelvi tanácsadásra is csak kismértékben térnek ki.

Mivel a tanulmány egyik célja, hogy felhívja a figyelmet a szervezett nyelvi menedzselés eme válfajának fontosságára, a tanulmány első felében a teljesség igénye nélkül bemutatom néhány európai nemzet nyelvi tanácsadó tevékenységét, intézményeit. A helyzetkép leírásán túl ennek hozadéka, hogy a más országokban sikeresen alkalmazott gyakorlatoknak a magyar gyakorlatba való átültetése hosszú távon hozzájárulhat a mai magyar nyelvi tanácsadó tevékenység megújításához.

Az egyes nemzetek nyelvi tanácsadással foglalkozó intézményeinek számbavétele után megvizsgáltam tevékenységüket a honlapjukon található tájékoztató szövegek, illetve - ha voltak ilyenek - tudományos közlemények, illetve a tanácsadó munkatársak e-mailes beszámolója alapján. Főként az alábbi szempontokra koncentráltam: a) a tanácsadás csatornája: telefonon vagy e-mailben, illetve egyéb módon (pl. személyes konzultáció); b) a tanácsadást végző munkatársak száma; c) az intézmény közzéteszi-e a korábbi kérdéseket és válaszokat; ha igen, milyen formában; d) az összegyült nyelvi anyag hasznosul-e a tudományos kutatásban.

\section{Nyelvi tanácsadás nálunk és más nemzeteknél}

\subsection{Svédország}

A svédországi nyelvi menedzselés helyzetét, intézményi hátterét Andersson (2000), Jernudd (2018), a magyar szakirodalomból Sándor (2002) és Péteri (2008) munkái alapján, valamint az egyes intézmények honlapján elérhető leírásokat felhasználva mutatom be. Nyelvi menedzseléssel Svédországban több intézmény foglalkozik. Az egyik az 1786-ban alapított Svéd Akadémia, amelynek fö tevékenysége a svéd nyelv szókincsének, nyelvtanának a leírása. A jelen tanulmány szempontjából a legfontosabb intézmény a Stockholmban található Svéd Nyelvi Tanács (Språkrådet), amely 1944 óta müködik föként állami, kisebb részben magáncégektől, magánszervezetektől származó támogatással. A Svéd Nyelvi Tanács a Svéd Nyelvi és Folklórintézet osztályaként működik, legfőbb tevékenységi köre a nyelvészeti, nyelvhasználati könyvek, folyóiratok megjelentetése, a hivatali nyelvhasználat egyszerübbé tétele, valamint a svéd és más hivatalos kisebbségi nyelvek (beleértve a svéd jelnyelvet) használatával kapcsolatos nyelvi tanácsadás.

A Svéd Nyelvi Tanács honlapján [1] részletes tájékoztatás olvasható a tanácsadó szolgálat müködéséről. Figyelemre méltóan kidolgozott az egyes kérdéstípusok kategorizálása, minden kategóriának megvan a maga külön alegysége a tanácsadó szolgálaton belül, külön e-mail-címmel és telefonszámmal. Nyelvi tanács kérhető 
a svéd nyelvröl (pl. helyesírási szabályok, kiejtés, nyelvjárások; továbbá publikus szövegek nyelvének egyszerüsítése, névtani kérdések), valamint számos kisebbségi nyelvröl (finn, jiddis, meänkieli, romani, számi, svéd jelnyelv).

A tanácsadó szolgálat különféle kiadványokat is megjelentet: szótárakat, glosszáriumokat, szabályzatokat, kézikönyveket. Két folyóiratuk is van, az egyik az évente négy alkalommal megjelenő, a közérthető svéd nyelvről szóló Klarspråk, a másik a svédországi finn kisebbségi nyelvhasználók negyedévente megjelenő folyóirata, a Kieliviesti (meänkieli nyelvü melléklettel) [3].

Andersson (2000: 88-9) a tanácsadás gyakorlatát bemutatva felhívja a figyelmet arra, hogy a tanácsadó munkatársak mindig „kondicionált” - azaz feltételekhez kötött - tanácsot adnak, nem pedig kategorikus „,helyes-helytelen” jellegüt: milyen kontextusban használható az adott kifejezés, milyen alternatívákat javasolnak például formális/informális helyzetben, beszélt/írott nyelvben stb. Gyakoriak az idegen szavakkal kapcsolatos kérdések is, például hogy egy-egy új szó milyen nemü, hogyan használatos többes számban, melyik paradigma szerint ragozódik, mi a normatív helyesírása stb. Jernudd (2018: 109-13) a 2013 márciusában érkezett 350 e-mailes kérdést az alábbi kategóriákba sorolta: a) az adott szóra kiterjedő részletes magyarázat kérése (pl. etimológia, változatok stb.); b) helyesírás (az összes kérdés legnagyobb része ide kapcsolódott, pl. kisbetü-nagybetü, alakváltozatok, idegen szavak helyesírása;); c) prepozíciók; d) főnevek és melléknevek (nyelvtani nem, határozottság, többes szám, létezik-e az adott névszó, a kettő közül melyik a helyes stb.); e) igék (pl. igekötők, létezik-e egy bizonyos ige, adott szövegkörnyezetben használható-e az adott ige); f) nyelvi produktumok értékelésre, véleményezésére vonatkozó megkeresések; g) egyéb kérdések. Andersson (2000: 89) megállapításával szemben e 350 e-mailes megkeresés között meglepően kevés angol vagy egyéb idegen szóval kapcsolatos kérdés akadt.

Svédország harmadik fontos nyelvi menedzseléssel foglalkozó szervezete az 1941-ben létrejött Svéd Szaknyelvi Központ (Terminologiecentrum) volt, amelynek munkáját a Svéd Nyelvi Tanács vette át. Ugyanez az intézmény vette át a nemzeti terminológiai adatbázis (Rikstermbanken) müködtetését is. A Szaknyelvi Központ honlapján korábban elérhető volt a beérkező szaknyelvi kérdések gyüjteménye is, jelenleg a Svéd Nyelvi Tanács adatbázisában is találhatók terminológiai kérdések. Jernudd (2018: 103-8) az alábbi főbb típuskérdéseket ismerteti: a) mit jelent az adott terminus; b) az egyes alakváltozatok közti különbség (szinonimák-e, van-e jelentésbeli különbség, melyik a helyes írásmód két eltérő közül); c) idegen terminusok svéd megfelelője utáni érdeklődés, hiányzó terminus egy adott fogalomra; d) „Swenglish”, azaz svédangol „keverékterminusokkal” kapcsolatos kérdések.

\subsection{Norvégia}

Norvégiát a nyelvi türelem mintaországaként szokás emlegetni sajátos nyelvi helyzete miatt (Baksy 2008; Jahr 2000; Omdal 2000; Sándor 2002), mivel két írott sztenderd nyelvváltozata van, amelyek kölcsönösen érthetök, és föleg morfológiai különbségek vannak köztük. Az egyik a dán nyelvhez közel álló bokmål ('könyv- 
nyelv'), a másik a norvég nyelvjárásokon alapuló nynorsk ('újnorvég'). Hivatalos beszélt nyelvi norma nem létezik Norvégiában, a dialektusok használata a médiában és a hivatalos érintkezésben is teljes mértékben elfogadott.

Oslóban található a nyelvi menedzselés fö intézménye, a Norvég Nyelvi Tanács (Språkrådet) [4], amely mindkét normával kapcsolatban ad hivatalos tanácsot állami szervek és a lakosság részére. Fő feladata a nyelvi kompetencia és tolerancia erösítése a különböző beszélt és írott nyelvváltozatokat illetően (Baksy 2008: 234). A Nyelvi Tanács több osztályra tagozódik (pl. szaknyelvek, oktatás, kommunikáció stb.), ezek egyike a nyelvi tanácsadás. Az intézmény honlapja [5] szerint jelenleg tíz dolgozója van a tanácsadói részlegnek, amelynek fóbb feladatai az alábbiak: nyelvi és helyesírási tanácsadás (nynorsk és bokmål) e-mailben, telefonon és a közösségi médiában; a norvég jelnyelv és a nemzeti kisebbségi nyelvek (kvén, romani és újabbak) iránti felelősségérzet növelése, a beszélőközösségekkel való együttmüködés; a földrajzi nevekkel kapcsolatos nyelvi menedzsment; nyelvi dokumentációk nyomon követése.

A nyelvi tanácsadás honlapján [6] számos hasznos információ található az alábbi három fö témakörben: 1) helyesírási szabályok (különírás-egybeírás, vesszőhasználat, rövidítések, kisbetü-nagybetü stb.); 2) gyakorlati nyelvtan (grammatikai alapfogalmak, felszólító mód, névmások használata); 3) az írott nyelvi stílussal kapcsolatos tanácsok (pl. hogyan kell hivatalos e-mailt írni, az írásbeli üzenetváltás nyelvi udvariassági formái stb.).

A nyelvi tanácsadás a honlap tanúsága szerint alapvetően írásban zajlik, telefonügyeletről nem található információ a honlapon. A tanácsadók javasolják az érdeklődőknek, hogy a kérdés elküldése előtt nézzenek utána a honlapon található adatbázisban [7], hátha megtalálják a választ a korábbi kérdésekre adott válaszok között. Minden kérdés bekerül a nyilvános adatbankba, a honlapon fel is hívják erre a figyelmet. A kérdés-válasz archívum mellett más hasznos adatbázisok is megtalálhatók ugyanitt: online szótárak, terminológiai adatbázisok, földrajzi és személynevekkel kapcsolatos tudnivalók.

\subsection{Finnország}

A finn helyzetet Minya (2008), Laihonen (2010) és Takács (2019) munkájára támaszkodva mutatom be. 1927-ben jött létre a Finn Nyelvi Bizottság, amely nyelvhelyességi kérdésekben adott tanácsot, majd 1945-ben létrejött egy nyelvi iroda, végül 1947-ben mindkettő állami intézmény lett. 1948-ban a nyelvi iroda befejezte a müködését. Az 1949-ben alakult új állami intézmény, a Finn Akadémia keretében új nyelvmüvelö szolgálat jött létre, amely lényegében hasonló formában müködött, mint az elődje. A tanácsadó szolgálatról a Magyar Nyelvőrben is jelent meg egy ismertető (Sadeniemi 1955), amelyböl megtudhatjuk, hogy az ötvenes években két fizetett munkatársat foglalkoztatott az intézmény, akik hétköznaponként 9-töl 14 óráig, szombatonként 9-töl 13 óráig válaszoltak a beérkező kérdésekre föként telefonon, de levélben és a sajtóban is (Sadeniemi 1955: 308).

Napjainkban a Honi Nyelvek Intézete (Kotimaisten kielten keskus, Kotus) a szervezett nyelvmenedzselés legfontosabb intézménye. A nyelvi bizottság a nyelv- 
használatot érintő kérdésekben dönt, a nyelvi iroda pedig a szótárfejlesztés mellett nyelvi tanácsadó szolgálatot müködtet. A finn köznyelven kívül a hivatalos nyelv, az EU-nyelv és a névadás a nyelvi menedzselés kiemelt területei.

A Honi Nyelvek Intézete tanácsadó szolgálatának adatbankjában (Kielitoimiston ohjepankki) [8] a helyesírási (pl. írásjegyek, számok, rövidítések; nevek; szavak; mondatok; szöveg) és nyelvhasználati kérdésekben témakörök szerint kereshetünk, de szabadszavas keresésre is lehetőség van. A nyelvhasználati témakörök között ilyen kérdésekre kaphatunk választ például: hogyan köszönjünk el egy levél végén, vagy hogyan rövidítsük levélben a címeket, fokozatokat. A honlapról tulajdonnevek helyesírásával kapcsolatban két link is elérhető: ezek a leggyakoribb család- és utónevek legfontosabb ragozott alakjait (általában a nominativust, genitivust, partitivust és allativust) mutatják meg. Akinek ennél gyorsabb segítségre van szüksége, telefonon is hívhatja a közönségszolgálatot.

Az intézmény honlapja alapján [9] a telefonos tanácsadás három fö területe (külön telefonszámmal): 1) általános nyelvi kérdések a finn nyelvről (finn nyelven); 2) névhasználattal kapcsolatos kérdések; 3) svéd nyelvvel kapcsolatos kérdések svéd nyelven. Az intézet munkatársai kérésre nyelvi szakvéleményeket, jelentéseket készítenek nyelvhasználati és névtani kérdésekben finn és svéd nyelven, ez a szolgáltatás többnyire díjköteles. A munkatársak tréningeket is tartanak a közérthető fogalmazás, nyelvhasználat, helyesírás témájában. A nyelvi iroda adja ki a Kielikello című folyóiratot, amelyben többek között a Finn Nyelvi Bizottság ajánlásait, állásfoglalásait közlik, valamint kérdésekre válaszolnak.

\section{4. Észtország}

A Tallinnban található Észt Nyelvi Intézet (Eesti Keele Instituut) állami tudományos és fejlesztési intézmény, amelynek főbb feladata az észt irodalmi nyelv, a nyelvjárások, valamint a rokon nyelvek kutatása, szótárkészítés, mindemellett nyelvi tanácsadó szolgálatot is müködtet (Víghné Szabó 2008). A honlapon olvasható leírás szerint [10] az intézet 1947-es létrejötte óta folyamatosan foglalkozik nyelvi tanácsadással: kezdetben a szótári részleg, majd 1973-tól a szaknyelvi és a helyesírási részleg keretein belül. A 2008-as szerkezeti átalakítás óta a nyelvi menedzsment osztálya látja el a nyelvi tanácsadói feladatokat.

A tanácsadás telefonon és 2004 óta e-mailben történik. A tanácsadók mind az Észt Nyelvi Intézet munkatársai, akik számos egyéb feladatuk mellett végzik ezt a munkát. Nyelvi tanácsot telefonon vagy e-mailben lehet kérni; az intézet munkatársai elsősorban a telefonos megkeresést javasolják részben annak gyorsasága miatt, részben azért, hogy bonyolultabb kérdések esetén lehetőség legyen a kérdéses nyelvi forma kontextusának a tisztázására. A hét öt munkanapjának mindegyikén más-más tanácsadó tart telefonügyeletet [11]. A tanácsadókhoz föleg az olyan kérdésekkel lehet fordulni, mint a helyesírás (kisbetü-nagybetü, tulajdonnevek írásmódja, központozás stb.), szavak toldalékolása, jelentésük, fogalmazási kérdések.

Az intézet honlapján [12] szabadon elérhetők a korábban feltett kérdések és a rájuk adott nyelvi tanácsadói válaszok. Az 1991 májusától 2003 novemberéig érke- 
zett kérdéseket és a rájuk adott válaszokat utólag vitték fel a létrehozott internetes adatbázisba, 2003 novembere óta pedig a kérdések és a válaszok közvetlenül oda kerülnek.

Felmerülö kérdés esetén a tanácsadók először az adatbázis átböngészését javasolják a közvetlen megkeresés elött. Az e-mail küldése a honlapon található ürlap kitöltésével lehetséges, a kérdés hossza legfeljebb 2000 karakter lehet. A válasz általában 1-3 munkanapon belül érkezik meg. Az ürlapon kulcsszavakat is meg kell adni a kérdéshez, továbbá a nyelvi tanácsadók kérik, hogy a kérdezők írják le a kérdés kontextusát.

Az írásos nyelvi tanácsadás egy sajátos válfaja a nyelvi szakvélemény készítése, amelyet kifejezetten a rendőrség, bíróságok stb. kérésére készítenek az intézet munkatársai. Nyelvi szakvéleményt nem adnak ki abban az esetben, ha a megkeresés írója a szóban forgó bírósági ügy egyik résztvevője.

A nyelvi tanácsadók nagy köztiszteletnek örvendenek az észt társadalomban. Fontosságukat mutatja, hogy országos jelentőségü, hivatalos dokumentumokat véleményeztek, lektoráltak, például magának az alkotmánynak a szövegét. A nyelvi tanácsadás népszerüségét mutatja, hogy a telefonkönyvekben a fontos segélyhívó számok között szerepel a számuk.

Ugyanakkor - ahogy a honlapjukon olvashatjuk - nem csupán a nagyközönség, hanem maguk a nyelvészek is profitálnak a hozzájuk érkező visszajelzésekből, hiszen így képet kapnak arról, melyek azok a nyelvi formák, változások, amelyek a legtöbb problémát okozzák a beszélőknek. A tanácsadók számos állami, tudományos és oktatási intézménnyel állnak kapcsolatban, nyelvi tréningeket tartanak a partnerintézmények dolgozóinak, véleményezik nyelvi produktumaikat.

\subsection{Németalföld}

Hollandia és Flandria 1980-ban kötött kétoldalú egyezményeként létrejött a Németalföldi Nyelvszövetség (Nederlandse Taalunie), amelynek 2004 óta Suriname is tagja. A hágai székhelyü hivatalos intézmény föleg a németalföldi nyelv oktatási, fordítási vonatkozásaival foglalkozik (Gúti-Varga 2008). Mindemellett nyelvi tanácsadásért is lehet a Nyelvszövetséghez fordulni. Az intézmény honlapján elérhető kérdés-válasz adatbázisban kulcsszavak alapján kereshetünk különféle nyelvhasználati, helyesírási témákban (pl. összetett szavak, szófajok, írásjelek stb.), de szabadszavas keresésre is lehetőség van [13]. Az adatbázisban található kérdéseket a Hollandiában és Belgiumban található nyelvi tanácsadó szolgálatok tapasztalatai alapján válogatták össze, és folyamatosan fejlesztik, bővítik. Az oldalon található kérdőív segítségével a felhasználók is megoszthatják észrevételeiket, javaslataikat az adatbázis fejlesztőivel [14].

Ha a felhasználó nem talál választ a kérdésére az adatbázisban, lehetősége van kérdését a honlapon található ürlapon keresztül elküldeni. A választ a holland Mi Nyelvünk Társaság (Het Genootschap Onze Taal) és a flamand Taaltelefoon szolgálat munkatársai válaszolják meg [15].

A Hollandiában található, nyelvi ismeretterjesztéssel foglalkozó Mi Nyelvünk Társaságba bárki beléphet, aki érdeklődik a németalföldi nyelv iránt. Az egyesület 
nyelvi tanácsadó szolgálata 1985 óta áll a nyelvi kérdésekben eligazításra vágyó beszélők rendelkezésére [16]. A nyelvi tanácsadáshoz - telefonon és írásban - nemcsak magánszemélyek szoktak fordulni, hanem különféle intézmények, cégek is. A szolgálat évente mintegy 3000 telefonos kérdésre válaszol. Az e-mailes tanácsadást az egyesület tagjai díjmentesen vehetik igénybe. A nyelvi tanácsadás munkatársai írják a honlapon olvasható nyelvi tanácsokat, és karbantartják a Spellingsite. nu [17] weboldalt, amely a Prisma Kiadóval együttműködve jött létre. Az oldalon mintegy százezer szó, rövidítés és tulajdonnév helyes írásmódja található meg, valamint az összes helyesírási szabály.

A nyelvi tanácsadók ezenkívül rendszeresen tartanak nyelvi tréningeket különféle cégek, vállalatok dolgozóinak, valamint évente tíz alkalommal megjelentetik A Mi Nyelvünk (Onze Taal) címü folyóiratot, amelyben különféle nyelvhasználati kérdésekről olvashatnak az érdeklődők közérthető stílusban: hogyan írhatunk olvashatóan, továbbá prezentáció tartása, a nyelv és a számítógép, érveléstechnika, szótárak, új szavak, etimológia, helyesírás, az ifjúság nyelve stb. [18]. A szerkesztők, trénerek és adminisztratív dolgozók mellett öt nyelvi tanácsadó munkatárs dolgozik az intézményben [19].

A telefonos tanácsadás mellett írásban is lehet kérdezni: Twitteren, Facebookon, és - az oldal ürlapján keresztül - e-mailben. A tanácsadók öt munkanapon belül válaszolnak [20].

Belgiumban egy kormányhivatal foglalkozik nyelvi tanácsadással. A flamand kormány hivatalos nyelvi tanácsadó szolgálata a brüsszeli székhelyü Taaltelefoon (szó szerint: nyelvi telefon), amely 1998-ban jött létre, célja a nyelvi tanácsadáson kívül a nyelvi ismeretterjesztés (pl. a honlapján és különféle információs kampányokon keresztül). A tanácsadó szolgálatot nemcsak az állampolgárok, hanem a flamand kormány is igénybe veszi oly módon, hogy a különféle kormányrendeleteket a tanácsadó szolgálat véleményezi [21]. A honlapon tematikus kereső is található, ahol a helyesírás, a szóhasználat, a fogalmazás, a nyelvtan különféle kérdéseiről lehet olvasni, továbbá megtalálhatjuk a helyesírási szabályok gyüjteményét és számos helyesírási tesztet is [22]. Neve ellenére a Taaltelefoon nem csupán telefonon fogad kérdéseket, hanem írásban is [23].

\subsection{Németország}

Európa egyik legrégebbi kultúrnyelveként Németországban igen sokrétű, gazdag hagyománya van a nyelvi menedzselésnek. E sokrétű hagyományról részletesen tájékozódhatunk Földes (2008) tanulmányában.

A mai német nyelv tudományos kutatását és dokumentációját a mannheimi Leibniz Német Nyelvi Intézet (Das Leibniz-Institut für Deutsche Sprache) [24] végzi, amely számos nyilvános adatbankot, korpuszt bocsát rendelkezésre. Nyelvi tanácsadással ugyan nem foglalkozik, de honlapján megtalálható a jelenleg müködő német nyelvi tanácsadó irodák listája.

A nyelvi menedzselést Németországban nem támogatják államilag, de az ezzel foglalkozó intézmények között léteznek olyanok, amelyek tevékenységét majdnem teljes mértékben közpénzből finanszírozzák. 
A szervezett nyelvmenedzselés egyik legfontosabb intézménye a wiesbadeni székhelyü Német Nyelvi Társaság (Gesellschaft für deutsche Sprache, GfdS), amelynek súlyponti tevékenysége a nyelvi tanácsadás. Az intézmény honlapján elérhetők a korábban feltett kérdések és válaszok [25] kategóriákba rendezve, például: rövidítések, kiejtés, anglicizmusok, különírás-egybeírás stb.

A nyelvi tanácsadás magánszemélyeknek és cégeknek, hivataloknak, különféle intézményeknek egyaránt elérhetö. Többnyire a nyelvtannal és a helyesírással, a szavak eredetével és jelentésével, a szöveg stílusával kapcsolatban várnak kérdéseket.

A telefonos tanácsadás a Német Nyelvi Társaság tagjainak, minisztériumoknak, valamint külföldi tanácskéröknek ingyenesen elérhető, akik nem tagjai a Társaságnak, azok a díjköteles telefonszámot hívhatják.

Írásban is lehet segítséget kérni, ez nem csupán a nyelvi tanácsadást foglalja magában, hanem szövegek korrektúrázására is lehetőség van. Ezek a szolgáltatások díjkötelesek, a társasági tagoknak azonban kedvezményes áron vagy ingyenesen igénybe vehetők [26]. Az intézmény névtani tanácsadással is szolgál a hozzájuk fordulóknak, amely szintén fizetős szolgáltatás [27]. A társaság kiadványa a Muttersprache címü, negyedévenként megjelenő folyóirat, amelyet 1890-ben alapítottak.

A GfdS-en kívül több nyelvi tanácsadó iroda is müködik vagy müködött Németországban (ezekröl részletesen 1. Riegel 2007: 38-41), például a Német Nyelvi Egyesület (Verein Deutsche Sprache, VDS).

\subsection{Csehország}

A csehországi nyelvmüvelés történetét, helyzetét részletesen Nekvapil (2008: 253-5), Lanstyák (2014: 21-2) és Tölgyesi (2008) munkája alapján mutatom be. Csehországban a nyelvi menedzselés nemcsak a nagyközönség körében rendelkezik nagy tekintéllyel, hanem a nyelvtudományban is elismert, kutatott területnek számít. A korszerű cseh nyelvművelés megteremtése a Prágai Iskola nyelvészeihez kapcsolódik, különösen Bohuslav Havránek, Vilém Mathesius és Roman Jakobson munkásságához, akik az 1930-as években újították meg a korábban purista elveket valló nyelvmüvelést, és akik a nyelvi folyamatokba való beavatkozást tudományosan megalapozható és társadalmilag hasznos tevékenységnek tartották. A Prágai Nyelvészkör a jelenkor standard cseh nyelvváltozatára fókuszált, amelynek müvelése (ezen leginkább a korpusztervezést értették) a standard változat egzakt leírásárán kell, hogy alapuljon. A nyelvmüvelés céljául egyrészt a standard nyelvváltozat stabilitásának a támogatását tüzték ki, másrészt annak funkcionális differenciálódását és stilisztikai gazdagodását (Havránek 1932, idézi Nekvapil 2008: 253-4). A stabilitáson azonban rugalmas stabilitást értettek, nem a nyelvi változások megakadályozására való törekvést.

Csehország helyzete több szempontból hasonló a magyarországihoz: a nyelvi tanácsadás legfóbb szerve, a Nyelvi Tanácsadó Központ (Jazyková poradna) ugyanúgy akadémiai bázisú, mint ahogy alapvetően Magyarországon is a korábban az Akadémiához tartozó Nyelvtudományi Intézetben müködik nyelvi ta- 
nácsadó szolgálat. ${ }^{3}$ (Utóbbival részletesen foglalkozom a tanulmány 4. fejezetében.) A Cseh Köztársaság Tudományos Akadémiájának Cseh Nyelvi Intézete a cseh nyelv állapotát, változását vizsgálja a középkortól napjainkig. A kutatás mind az írott, mind a beszélt nyelvre irányul, sztenderd és nem sztenderd változatokra egyaránt. Az intézetben az alábbi osztályok müködnek: dialektológiai, etimológiai, leíró nyelvészeti, névtani, lexikográfiai, szociolingvisztikai, történeti nyelvészeti, valamint a nyelvmüvelő osztály. A jelenleg 15 főből álló nyelvmüvelő osztály fő feladata a tudományos kutatás, amely szorosan összefonódik a gyakorlati nyelvi tanácsadással. Az osztály munkatársai együttmüködnek a cseh rádióval és televízióval, napilapokkal és magazinokkal, ismeretterjesztő előadásokat tartanak a cseh nyelvröl. Emellett müködtetik a Nyelvi Tanácsadó Központot, amelyhez 1946 óta fordulhatnak a nyelvhasználók [28].

A nyelvi tanácsadás kizárólag telefonon zajlik, az ügyeletes nyelvi tanácsadó egy könyvtárral és számítógéppel felszerelt elkülönített szobában várja a telefonhívásokat. A számítógép biztosítja a hozzáférést a különféle nyelvi adatbázisokhoz. A munkatársak naponta átlagosan 70 telefonos kérdést válaszolnak meg (Beneš et al. 2018: 120). 1999 és 2011 között e-mailes tanácsadásra is lehetőség volt (Černá 2017: 268).

Beneš és munkatársai (2018: 120-1) tanulmányukban az alábbi leggyakoribb kérdéstípusokat különítették el:

1. Szótári kodifikációval nem rendelkező kölcsönszókkal kapcsolatos kérdések.

2. Olyan belső keletkezésủ alakváltozatok, amelyek nincsenek kodifikálva, így a nyelvhasználók számára nincs egyértelmü javaslat arra vonatkozólag, hogy használhatók-e ezek a változatok.

3. Létezik-e egy szó vagy szóalak?

4. Fogalmazási kérdések - grammatikai szempontból.

5. Fogalmazási kérdések - jelentéstani szempontból.

2009-ben jött létre a beérkezett és megválaszolt kérdésekből álló internetes nyelvi útmutató (Internetová jazyková př́ručka), amely egy 60000 bejegyzésből álló szótári részből, illetve egy kifejtős részből áll, ez utóbbi a kérdezők által gyakran említett nyelvi jelenségek magyarázatát tartalmazza. Az adatbázisban számos témakör alapján kereshetünk: helyesírás (pl. különírás-egybeírás, központozás, kisbetü-nagybetü), szóképzés, alaktan; különféle tulajdonnévtípusok (személynevek, földrajzi nevek, intézménynevek) ragozása, a mondat szerkezete, rövidítések, számok stb. [29].

Mivel Csehországban a nyelvi tanácsadó tevékenység akadémiai kutatóintézethez kötődik, a gyakorlati nyelvi tanácsadás szorosan összekapcsolódik a tudományos kutatással. A nyelvészeti kutatások a nyelvi tanácsadást a nyelvészek és a nagyközönség közti párbeszédként értelmezik, ahol mindkét fél szerepe fontos, bár

3 A tanulmány írásának kezdetekor (2019. július-augusztus) a kutatóintézetek a Magyar Tudományos Akadémia kutatóintézet-hálózatához tartoztak, de 2019 szeptemberétől az akadémiai kutatóhelyek - így a Nyelvtudományi Intézet is - az MTA-tól az Eötvös Loránd Kutatási Hálózatba kerültek át. 
lényegesen különböző. A nyelvhasználók kérdeznek, a nyelvészek hivatalos nyelvi tanácsot, ajánlást adnak. Ugyanakkor a nyelvészek maguk is információkhoz jutnak: az érkezett megkeresések az aktuális nyelvhasználatról, magukról a nyelvhasználókról, illetve az ő nyelvi attitüdjeikről nyújtanak értékes szociolingvisztikai adatokat. E nyelvi adatok előnye, hogy - ellentétben például a kérdőíves vizsgálatokéival spontán nyert adatok, hiszen nem a nyelvészek, hanem a beszélők kezdeményezik a párbeszédet. Ugyanakkor a nyelvi tanácsadásnak mint információforrásnak megvannak a maga korlátai, mivel csak azoktól a beszélöktöl származnak az információk, akik nyelvi problémáikkal megkeresik a tanácsadó központot. Nem garantálható azonban, hogy ezek a beszélök az egész beszélöközösséget reprezentálják (Uhlírová 1997: 83).

A Nyelvi Tanácsadó Központ munkatársai tartják karban azt a terjedelmes adatbázist, amely a korábbi évek megkereséseit tartalmazza. Már a kilencvenes évek eleje óta számítógépes formában archiválják a kérdéseket és a válaszokat. Az 1992ben létrejött adatbázis 1996 végén 1400 rekordot tartalmazott, beleértve az 1992 óta érkezett összes levelet és faxot, válogatott telefonhívások és személyes konzultációk lejegyzett szövegét. Az adatbázis a technikai és bibliográfiai azonosító adatok mellett (a kérdés és a válasz dátuma, a kérdező neve és címe, a válaszoló neve) a kérdező szociológiai adatait (foglalkozását), a kulcsszavakkal leírt nyelvi problémát és annak megoldását tartalmazta, esetenként a nyelvi probléma pragmatikai kontextusát is (motivációk, attitüdök, kritikák, érzelmek) (Uhlířová 1997: 83-4).

2016 óta az összes beérkezett telefonhívást rögzítik, a rögzített adatok feldolgozása folyamatosan történik. A cél egy olyan nyelvi struktúra létrehozása, amely lehetővé teszi a rögzített telefonos megkeresések kategorizálását és leírását. A nyelvészetileg strukturált adatbázis nyelvészeti részét a nyelvmüvelő osztály munkatársai, az informatikai részét a Nyugat-csehországi Egyetem (Pilsen) Alkalmazott Tudományi Karának munkatársai végzik. 2016-tól 2018-ig több mint 8000 telefonhívás került az adatbázisba. A hangfelvételeket saját fejlesztésű szoftver segítségével jegyzik le (Zajíc et al. 2019), és különféle kulcsszavakkal annotálják (Černá 2017; Dufek 2018).

\subsection{Magyarország és a határon túli magyar nyelvi irodák}

Magyarországon napjainkban két intézmény foglalkozik nyelvi tanácsadással: a Nyelvtudományi Intézetben müködő nyelvi tanácsadó szolgálat, valamint a Magyar Nyelvi Szolgáltató Iroda. Mivel az előbbivel a következő (4.) fejezetben foglalkozom részletesen, itt csak a második intézményt mutatom be.

A szervezett nyelvi menedzselés fontos intézménye Magyarországon a 2006-ban létrejött Magyar Nyelvi Szolgáltató Iroda (MANYSZI). Az iroda számos, nyelvvel kapcsolatos szolgáltatást nyújt: nyelvi szakvélemények készítése, szövegértelmezés, korrektúra, szöveggondozás, nyilvános szövegek közérthetővé tétele, beszédírás, fordítás és fordított szövegek lektorálása, nyelvi és kommunikációs tréningek tartása [30]. Az iroda egyik legnépszerübb szolgáltatása a nyelvi gyorsszolgálat. A kérdéseket az iroda honlapján található ürlapon keresztül lehet feltenni, a ta- 
nácsadók 24 órán belül válaszolnak [31]. A tanácsadók (a honlap szerint jelenleg 9 fö) társadalmi munkában látják el feladatukat, és kéthetente váltják egymást [32]. Az eddig adott válaszok szócikkek formájában bárki által elérhetők, az adatbázisban jelenleg 20000 szócikk található [33]. A beérkezett kérdésekből és válaszokból az Édes Anyanyelvünk folyóirat rendszeresen közöl válogatást, időnként pedig tudományos publikációk is jelennek meg a témában (legutóbb pl. Minya 2019).

2001-ben négy nagy magyarlakta régióban, Erdélyben, Felvidéken, Vajdaságban és Kárpátalján nyelvi irodák alakultak a Magyar Tudományos Akadémia támogatásával: a kolozsvári Szabó T. Attila Nyelvi Intézet (sepsiszentgyörgyi filiáléval), a dunaszerdahelyi Gramma Nyelvi Iroda, a szabadkai Magyarságkutató Tudományos Társaság, valamint a beregszászi székhelyü Hodinka Antal Intézet. Ezekhez csatlakozott 2007-ben az ausztriai, alsóőri Imre Samu Nyelvi Intézet, a 2013-ban létrejött vajdasági Verbi Nyelvi Kutatómühely, majd a 2014-ben megalapított horvátországi (eszéki) Glotta Nyelvi Intézet. A határon túli magyar nyelvi irodákat a később létrejött Termini Magyar Nyelvi Kutatóhálózat fogja össze (Csernicskó et al. 2005; Péntek 2008). A felsorolt intézmények nem mindegyike végez nyelvi tanácsadást, így csak azoknak a tevékenységét ismertetem az alábbiakban, amelyek legalább alkalmilag nyújtanak eligazítást nyelvi kérdésekben a hozzájuk fordulóknak.

\subsubsection{Gramma Nyelvi Iroda}

A szlovákiai kutatóállomás (Gramma Nyelvi Iroda) 2001-től 2015-ig müködött önálló intézményként, 2002-től nyelvi tanácsadó tevékenységet is folytatott. Teljes vagy részmunkaidős dolgozója sosem volt, pozsonyi és nyitrai nyelvészek voltak a munkatársai. 2002-től telefonos tanácsadást is nyújtottak, hetente egy alkalommal telefonügyeletet tartottak. Az e-mailes megkeresések ez idő tájt még ritkábbak voltak, de ezen a csatornán is folyt nyelvi tanácsadás. Később a telefonügyelet megszünt, 2010-től már csak e-mailben érkező kérdéseket válaszoltak meg a tanácsadó szolgálat munkatársai

2002 és 2015 között évente átlagosan 150-180 kérdésre válaszoltak, ezek jellege a gyakoriságot illetően a következő volt: 1) szlovákból magyarra való fordítás (föként jogi-közigazgatási, ill. oktatási terminusoké); 2) helyesírás (melyik a helyesírási normának megfelelő írásmód a magyarban?); 3) nyelvhelyesség (hogy mondjuk „helyesen” magyarul?), 4) nyelvi jogok (mit szabad magyarul feltüntetni és mit nem, pl. hirdető- vagy tájékoztató táblákon). A nyelvi tanácsadó szolgálatot leggyakrabban önkormányzati hivatalok dolgozói, újságírók, szerkesztők, fordítók, pedagógusok, kulturális intézmények dolgozói keresték meg.

A nyelvi iroda munkatársai a leggyakoribb kérdésekre adott válaszokat ismeretterjesztő cikkek formájában is feldolgozták, ezek az Új Szó címü napilap Otthonunk a Nyelv címü rovatában, illetve a Csallóköz címü regionális hetilap nyelvi rovatában jelentek meg, közülük több a Pátria Rádió Hogyan mondjuk? címü müsorában is elhangzott.

2016-tól az iroda különböző okok miatt már nem tudott a régi felállásban müködni, néhány munkatárs betagozódott a somorjai Fórum Kisebbségkutató Intézetbe, ahol máig önálló kutatócsoportként dolgoznak. A tanácsadó tevékenységük azonban 
megszünt. Az intézményes nyelvi tanácsadás megszünése ellenére a leghüségesebb kérdezők máig megkeresik az egykori közönségszolgálat munkatársait egyetemi elérhetöségükön.

\subsubsection{Hodinka Antal Nyelvészeti Kutatóközpont}

A 2001-ben alapított beregszászi intézmény kutatóközpontként müködik, ebből adódóan nem a nyelvi tanácsadás a fö profilja. Összesen 5 munkatársa van: 1 intézetvezető, 2 kutató és 1 fiatal kutató teljes, illetve 1 fiatal kutató részmunkaidőben. Nyelvi tanácsadást alkalomszerüen végeznek, rendszerint önkormányzatok, szervezetek, intézmények fordulnak hozzájuk ilyen jellegü kérésekkel. Adatbázist vagy részletes nyilvántartást nem vezetnek a megkeresésekről, az így összegyült anyagot a kutatóközpont munkatársai levelezésükben archiválják. A megkereséseket olykor a nyelvi problémákkal foglalkozó, a Termini Kutatóhálózatban folyó közös kutatási programban, illetve tudományos publikációkban használják fel.

Az alkalomszerü nyelvi tanácsadás e-mailben vagy levélben történik, a megkeresés módjától függően. A fentiekből adódóan telefonos tanácsadó szolgálatot nem tartanak fenn.

\subsubsection{Szabó T. Attila Nyelvi Intézet}

A 2001-ben létrejött kolozsvári intézmény alapvetően e-mailben végez nyelvi tanácsadást. Korábban telefonszolgálat is müködött, de mivel mind a hat munkatárs főállás mellett, részmunkaidőben látja el itteni feladatait, a telefonügyelet fenntartására jelenleg nincs lehetőség. A nyelvi tanácsadás anyagát a Termini magyar-magyar szótárban [34] és a nyelvi problémák adatbázisának az építésében használják fel.

\subsubsection{Imre Samu Nyelvi Intézet}

A 2007-ben létrejött alsóőri székhelyü intézmény is alapvetően kutatási feladatokkal foglalkozik, nyelvi tanácsadást alkalmilag végez, a dolgozók társadalmi munkában látják el az ilyen jellegü feladatokat. Ebböl adódóan szervezett közönségszolgálatuk, előre kijelölt ügyeleti időpontjuk nincs. Az intézet munkatársai a megkeresés jellegétől függően (írásban, telefonon, személyesen) bármilyen kommunikációs csatornán adnak nyelvi tanácsot a hozzájuk fordulóknak. Az így összegyült nyelvi anyag közvetve hasznosul a tudományos kutatásokban a Termini magyar-magyar szótáron keresztül [34]. (Az intézetről részletesen 1. Szoták 2009).

\section{A Nyelvtudományi Intézet nyelvi tanácsadó szolgálata}

Az Intézethez kötődő nyelvi tanácsadás azt a szakmai hagyományt viszi tovább, amelyet a Magyar Tudományos Akadémiával intézményesült nyelvmúvelés az elmúlt évszázadokban betöltött. Az Intézet közönségszolgálatának országos jelentőségénél fogva meghatározó szerepe van a nyelvi ismeretterjesztésben. Részben emiatt, részben pedig - a nyelvi tanácsadás munkatársaként - saját személyes érintettségem okán foglalkozom kiemelten a Nyelvtudományi Intézetben működő nyelvi közönségszolgálat múltjával, jelenével és jövőjével. 


\subsection{A múlt}

Visszatekintve az intézet történetére, a Magyar Tudományos Akadémia 1949-ben létrejött Nyelvtudományi Intézetének szervezeti felépítése fokozatosan alakult ki. Kezdetben inkább csak munkacsoportok tevékenykedtek, mintsem osztályok. Lőrincze Lajos 1951-ben például Nyelvmüvelö Munkaközösségként említi azoknak az intézeti munkatársaknak a csoportját, akik a Magyar Nyelv, a Magyar Nyelvör, a Magyarosan és az Erdélyi Múzeum addig megjelent köteteinek feldolgozásával létrehozták az úgynevezett nyelvművelési adattárat, amely nagy segítséget nyújtott nekik a nagyközönség részéről érkezett kérdések megválaszolásában. Az intézet, illetöleg a munkaközösség számos kérdést kapott levélben és telefonon, de többen személyesen is felkeresték őket. Az érdeklődők főleg szerkesztőségek, kiadók, minisztériumok, az Akadémia különböző osztályai, diákok stb. közül kerültek ki, a kérdések nagy része pedig helyesírási jellegű volt (különírás-egybeírás, idegen szavak írásmódja) (Lőrincze 1951: 81-2).

1952-ben öt osztály létezett a Nyelvtudományi Intézetben: Magyar Osztály, Fonetikai Osztály, Idegen Nyelvek Osztálya, Finnugor Osztály, Értelmező Szótári Osztály (Kiss 2000: 12). A nyelvmüvelés kérdéseivel foglalkozó, a közönségszolgálatot is müködtető munkatársak tömörülése ezúttal Nyelvmüvelö Csoportként szerepel az MTA Nyelvmüvelő Főbizottságának híreiben (Hírek 1954).

1955-re már világossá vált, hogy a nyelvi közönségszolgálat iránti fokozódó érdeklödés, a tanácsadást végző munkatársakra irányuló nagy mennyiségü munka a közönségszolgálat intézményi keretének az átszervezését kívánja meg (Tompa 1955). Tompa József beszámolójából tudjuk, hogy a telefonos tanácsadást alapvetően a Magyar Osztály látta el ez idő tájt, és a legtöbb levélre is ennek az osztálynak a munkatársai válaszoltak, bár időnként igénybe vették más osztályok - sőt esetenként más intézmények dolgozóinak - a segítségét, például a szókészleti kérdések megválaszolásába a Szótári Osztály munkatársait is bevonták. A munkacsoport szervezési szálai Lőrincze Lajos kezében futottak össze, az írásbeli levelezést pedig főleg Tompa József irányította. Tompa beszámolójából kiderül, hogy ekkorra már problémát jelentett a munkacsoport dolgozóinak, hogy intézeti kutatómunkájuk, ,tervfeladataik" mellett egyúttal a többirányú és mélyebb kutatást, nagyobb szervezést kívánó közönségszolgálati munkát is ellássák. Így felvetődött (nem is egyszer), hogy a közönségszolgálat számára egészen külön személyi keretet létesítsen az Intézet, és ezt az egységet az intézeti osztályokból külön emeljék ki. Ez a gondolat azonban 1955-ben még nem látszott megvalósíthatónak, mivel a közönségszolgálati munka ez idő tájt még nem volt egyenletes mennyiségü: „naponta, hetente egyszer megháromszorozódik, egyszer ismét felére csökken" (Tompa 1955: 109). Tompa arra is felhívja a figyelmet, hogy a nyelvi tanácsadás olyan sok munkaterületen igényel nagy tapasztalatot, hogy néhány szakember aligha tudná megfelelöen végezni, noha a munka végzése során tömérdek hasznos tapasztalattal gazdagodnak a tanácsadást végző kollégák. Tompa azzal zárja cikkét, hogy a szervezet kérdése változatlanul napirendi pont, és folyamatosan keresik hozzá a leghasznosabb, leggazdaságosabb keretet. Végül az 1959-es „Anyanyelvi müveltségünk” címü konferencián (Rácz 1960) 
született meg a határozat az új intézményi egység létrejöttéről: „A Nyelvtudományi Intézet tudományos munkaerőinek megfelelő átcsoportosítása s lehetőleg számbeli megerősítése útján minél előbb el kell kezdeni az intézet nyelvmüvelő osztályának megszervezését" - olvashatjuk a pécsi nyelvmüvelő konferenciáról (1959. október 2-4.) írott Magyar Nyelv-beli beszámolóban (Beszámoló 1960: 151).

A nyelvi tanácsadás történetében 1957 is fontos évszám: ez év júniusától kezdve működik folyamatosan a korábban csak alkalmi telefonos tanácsadó szolgálat (Lőrincze 1964). A közönségszolgálati munkatársak ekkortól kezdték el vezetni az úgynevezett közönségszolgálati naplókat, amelyben főleg a telefonon érkező kérdéseket és az azokra adott válaszokat rögzítették. Az első füzet első bejegyzését egy 1970-es Magyar Nemzet-beli cikk alapján 1957. június 3-án végezték (Koródy 1970); ezt az adatot a Nyelvtudományi Intézetben ma is meglévő 66 darab fennmaradt napló közül az elsőt fellapozva magam is meg tudom erősíteni.

Az intézeti közönségszolgálat végül valóban új szervezeti egységbe került. A Nyelvművelő Bizottság 1960. november 2-ai ülésén a bizottság titkára már arról számolt be, hogy megalakult a Nyelvtudományi Intézet Nyelvmüvelő Osztálya, egyúttal a beszámoló (Grétsy 1961) ismerteti a nyelvművelő közönségszolgálat munkáját, olvashatunk a telefonhívások és a beérkezett, megválaszolt levelek menynyiségéről, a kérdezők köréről (kiadók, szerkesztőségek, gyárak, minisztériumok, illetőleg tanárok, fordítók, háziasszonyok), valamint a főbb kérdéstípusokról. A bizottsági jelentés a telefonhívások és a levelek számának folyamatos növekedéséröl számol be, az elöbbit a napisajtóban megjelent riportok és a közönségszolgálat munkáját ismertető cikkek hatásának, az utóbbit az Édes Anyanyelvünk rádiómüsor hatásának tulajdonítva. A beszámolóból megtudhatjuk, hogy a levelekre föleg a Nyelvmüvelö Osztály munkatársai válaszoltak, de szükség esetén más osztályok dolgozói is bekapcsolódtak ebbe a munkába. A szokásos helyesírási, nyelvhelyességi kérdéseken kívül érkeztek olyan kérések is, amelyek egy-egy megjelenendő politikai, műszaki vagy akár nyelvművelő cikk kéziratának átnézésére, nyelvi lektorálására irányultak (a rövidebbeket át is nézték a közönségszolgálat munkatársai). A közérdekübb kérdéseket és válaszokat rendszeresen publikálták a Magyar Nyelvőrben. A Nyelvőr-beli rovatnak a címe „A Nyelvtudományi Intézet nyelvmüvelö csoportjának levelesládájából" volt 1955-től, és a címbeli csoport elnevezés megmaradt a következő három évtizedben is, noha a közönségszolgálat 1960-tól a Nyelvmüvelő Osztály keretében müködött. Maga a rovat 1981-ig létezett ezen a néven.

Ruzsiczky Éva (1961) Magyar Nyelvőr-beli írásában részletesen beszámol a közönségszolgálati munkáról, különös tekintettel a telefonos tanácsadásra. A szerző a telefonhívásokról vezetett közönségszolgálati naplók alapján a telefonhívások mennyiségének növekedését állapította meg: 1958 januárjában körülbelül százan, 1959 januárjában viszont már mintegy százharmincan kértek tanácsot. A leggyakrabban ismétlődő kérdések ebben az időszakban a következők voltak: bocsát bocsájt, helység vagy helyiség, egyelöre vagy egyenlöre; mi a különbség a -ként/ -kint és az -nként toldalék között; tudniok tudniuk, szíveskedjen szíveskedjék ragos változatok; személynevekkel alkotott szerkezetek: Szabóné tanító vagy Szabóné tanítónő; Kovács Mária kartárs vagy Kovács Mária kartársnő. Ugyancsak gyakran 
kérdeztek rá arra, hogy egy-egy konkrét kifejezésben az ide, ott, rá, tovább stb. határozószó-e vagy igekötő, és így külön vagy egybe kell írni az adott alakulatot (Ruzsiczky 1961).

Lőrincze Lajos a Nyelvművelő Munkabizottság 1962-es elnöki beszámolójában a nyelvmüvelö, nyelvi ismeretterjesztő munka legmindennapibb formájának nevezi az intézeti közönségszolgálatot, amelynek rendje, módszere ekkorra már kialakulni látszott. A beszámoló említést tesz a közönségszolgálati naplókról, amelyekbe nemcsak a kérdéseket és a feleleteket rögzítik a tanácsadók, hanem a kérdező személy nevét és munkahelyét is. Lörincze hangsúlyozza, hogy e feljegyzéseknek nemcsak statisztikai szempontból van jelentőségük, hanem arra is rámutatnak, milyen kérdések érdeklik aktuálisan a beszélőket, valamint kétes, vitás esetekben az egyes munkatársak esetleges eltérő véleményének, nézetének az összeegyeztetésére is szolgálnak. A beszámolóból továbbá azt is megtudhatjuk, hogy más városokban is történtek kezdeményezések hasonló nyelvi közönségszolgálatok kialakítására, például a szegedi egyetem magyar nyelvészeti tanszékén is mindennap tartottak ez idő tájt egyórás telefonügyeletet, de sokan keresték fel nyelvi kérdéseikkel a debreceni és a pécsi egyetemet is (Lőrincze 1962: 131-2).

A hatvanas évek elején a közönségszolgálat népszerüsége egyre nőtt a nyelvhasználók körében, ezt jól mutatja, hogy nemcsak a nyelvtudományi folyóiratok, hanem napilapok cikkei is ismertették a müködését, például [teknős] aláírással 1961-ban jelent meg róla cikk a Magyar Nemzetben. E cikkből tudhatjuk például, hogy ez idő tájt átlagosan tíz telefonhívás érkezett naponta, és évente 600-700 levél. Az MTA Nyelvmüvelő Munkabizottságának beszámolója szerint 1964-ben körülbelül 3500 telefonhívásra és 935 levélre válaszoltak a közönségszolgálat munkatársai, és ekkor már folytak az 1980-1985-ben megjelent Nyelvmüvelö kéziszótár munkálatai (Grétsy 1965). Ebben az évben jelent meg az intézeti levelezés alapján készült nyelvmüvelő kötet (Ferenczy-Ruzsiczky [szerk.] 1964), de az általános érdeklődésre számot tartó kérdéseket és feleleteket a Nyelvőr már korában is rendszeresen közölte. A hatvanas években élénk munka folyt az osztályon: a munkatársak nyelvmüvelő cikkeket, tanulmányokat írtak, ismeretterjesztő elöadásokat tartottak, különféle kiadványokon dolgoztak, szervezték és tartották a nyelvmüvelő elöadásokat, mindezt a közönségszolgálat müködtetése mellett. Az egyre növekvő feladatok jobb megoldása érdekében az Intézet több tagját felmentette egyéb munkák végzése alól, hogy teljes munkaidejüket a nyelvmüvelésnek szentelhessék. Az intézet nyelvmüvelőinek igen nagy részük volt abban, hogy a hatvanas évek elején a müszaki nyelvmüvelés olyan nagy mértékben fellendült (Fábián 1970). Ezekben az években számos olyan kérdés érkezett, amelyekkel bíróság vagy döntőbizottság elé került vitás ügyekben kértek nyelvészeti szakvéleményt.

Az 1970-es években az intézet közönségszolgálati munkája változatlan népszerüségnek örvendett. Koródi József (1970) cikkéből azt is megtudhatjuk, hogy 1970ben az intézet három munkatársa dolgozott rendszeresen a telefonnál: Lovas Gizella négy napig, Szüts László és Héra Zoltánné egy-egy napig volt szolgálatban.

Az osztály vezetését 1971-től Grétsy László vette át Lőrincze Lajostól (Balázs 2007). Ebben az évtizedben újabb átalakítások történtek a Nyelvtudományi Intézet 
szervezetében, a Nyelvmüvelő Osztály új névvel folytatta tevékenységét. 1973-ban a Nyelvtudományi Intézet hét osztálya közül a Mai Magyar Nyelv Osztályának keretén belül müködött az immár két évtizedes múltra visszatekintő közönségszolgálat (Kiss 2001: 19). A Nyelvtudományi Intézet 1972-1975-ös középtávú munkatervéböl kiderül, hogy 1974-re elkészült a Nyelvmüvelö kézikönyv előzetes kézirata, valamint ebben a munkatervben tünik fel elöször - adataim alapján - a közönségszolgálat újabb, ma is használt elnevezése, a nyelvi tanácsadó szolgálat (Imre 1973). A hetvenes években a kézikönyv munkálataival egy időben sorra jelennek meg olyan szintézisek, összefoglalók az osztály munkatársaitól, mint például Kovalovszky Miklós Nyelvfejlődés, nyelvhelyesség (1977) müve, valamint Grétsy László szerkesztésében a Mai magyar nyelvünk (1976) és a Hivatalos nyelvünk kézikönyve (1976, második kiadásban 1978).

A nyolcvanas években - továbbra is Grétsy László vezetésével - folytatódott a Mai Magyar Nyelvi Osztály és a közönségszolgálat müködése, a létszám ekkoriban 10 fö fölött mozgott. A nyolcvanas évek elején a 161-053-as telefonszámon kérhettek nyelvi tanácsot az érdeklődők, és 1974-től a Nyelvtudományi Intézet új helyén, a budai Várban, a Szentháromság utca 2. szám alatt délelőtt fél kilenctől délután fél kettőig személyesen is meg lehetett keresni a közönségszolgálat munkatársait (Népszabadság 1982). 1980-ban megjelent a szintézis, a Nyelvmüvelö kézikönyv első, majd 1985-ben a második kötete. Majd számos tanulmánykötet is az osztály munkatársainak részvételével: Nyelvészet és tömegkommunikáció (Grétsy [szerk.] 1985); Nyelvi divatok (Bíró - Tolcsvai Nagy 1985), Szaknyelvi divatok (Bíró 1989).

Az osztály vezetését Grétsy László távozásával 1988-ban Kemény Gábor vette át, aki 1993 végéig irányította a munkát. Ez idő tájt Herman József volt a Nyelvtudományi Intézet igazgatója, akinek 1988-as, a Magyar Nyelvben közzétett munkatervéből tájékozódhatunk a Mai Magyar Nyelvi Osztály tevékenységéröl, terveiröl. 1983-tól folytak az 1980-1985 között megjelent Nyelvmüvelö kézikönyv átdolgozott, kisebb terjedelmü, a nagyközönségnek szóló változatának, a Nyelvmüvelö kéziszótárnak (akkori munkanevén: a Nyelvmüvelö kisszótárnak) a munkálatai, és a társadalmi nyelvmüvelés keretében továbbra is folyamatosan zajlott - a nyelvi lektorálás, nyelvi ismeretterjesztő rovatok és müsorok szerkesztése, előadások tartása mellett - a nyelvmüvelö közönségszolgálat munkája telefonon és írásban (Herman 1988). Ennek az időszaknak a munkájáról - a telefonos tanácsadásra fókuszálva - Eőry Vilma (1994) tanulmányából tájékozódhatunk, aki a közönségszolgálati naplók egy évének anyagát tekintette át (1988. szeptember 1-jétől 1989. augusztus 31-ig), összesen 1512 kérdést. Ahogy három évtizeddel korábban, a nyolcvanas évek végén is a helyesírásra vonatkozik a kérdések legnagyobb része $(88 \%$-a), míg a többi kérdés megoszlása a következő: a nyelvvel, a nyelvhasználattal foglalkozó kérdés: 8,8\%, nem nyelvi kérdés: 3,2\%. A kérdések jelentős része (96,8\%-a) az írott nyelvvel kapcsolatos. Eőry kitér a kérdezők körére is, akik bár nem alkotnak szociológiailag egységes csoportot, az a tendencia figyelhető meg, hogy inkább a közép-, illetve az idősebb korosztályhoz tartoznak, érettségivel vagy diplomával rendelkeznek, többségük valamilyen szellemi vagy adminisztratív tevékenységet végez; különösen sok köztük a nyomdai, a rádiós vagy tévés szerkesztő, a lektor, a fordító, de 
nem ritka a gépíró sem. A kilencvenes évek első felének kutatási eredményei két kötetben jelentek meg: a Normatudat - nyelvi norma (Kemény [szerk.] 1992) és A magyar nyelvi norma érvényesülése napjaink nyelvhasználatában címü munkákban (Kemény-Kardos [szerk.] 1994).

Bár a Nyelvtudományi Intézet Mai Magyar Nyelvi Osztálya 1994. január l-jétől (ismét) a Nyelvmüvelő Osztály nevet vette fel (Kemény 1996: 381), az 1990-es évek második felében a nyelvmüvelés a nyelvtudomány perifériájára került (a nyelvmüvelésről szóló vitákat összefoglalja Minya 2005), így a Nyelvtudományi Intézetből is fokozatosan kiszorulni látszott. A Nyelvtudományi Intézet fennállásának ötvenedik évfordulóján (1999) a Nyelvmüvelő Osztály vezetője Szüts László volt, az osztály létszáma ekkorra már jelentősen csökkent a nyolcvanas évekhez képest: három fö- és egy félállású munkatárs látta el a feladatokat (Balázs 2005: 301). Heti öt munkanapon tartottak telefonügyeletet, és évente mintegy 250-300 telefonálónak adtak felvilágosítást elsősorban helyesírási és nyelvhelyességi kérdésekben. Levélben évente 80-100 érdeklődőnek válaszoltak. Az internet elterjedésével a 90-es években megjelent az e-mailes tanácsadás: 1998 óta e-mailben is fogadnak kérdéseket a közönségszolgálat munkatársai (MTA Nyelvtudományi Intézet 1999: 43). A kilencvenes években az osztály fő kutatási témái a következők voltak: Szüts László vezetésével zajlott a magyar nyelvmüvelés-történet válogatott bibliográfiájának az összeállítása, valamint Heltainé Nagy Erzsébet vezetésével normatív nyelvészeti vizsgálatokat végeztek. (E két munka eredményei nem kerültek publikálásra.) Ebben az időszakban Kemény Gábor a stilisztikai szöveginterpretáció elméleti és módszertani problémáival foglalkozott. (Ezt a kutatást az osztályról való távozása után önálló kutatási projektum keretében folytatta 1994-től 2010-ig.) Mindezek mellett az osztály munkatársai változatlanul végezték a gyakorlati nyelvmüvelő tevékenységet: a közönségszolgálat müködtetésén túl az Anyanyelvápolók Szövetségével és a TIT-tel együtt szervezték a magyar nyelv heti előadás-sorozatokat, és évenként 3040 tudomány-népszerüsítő előadást tartottak Budapesten és vidéken. Az ezredforduló után a létszám tovább csökkent, 2002-ben a Nyelvmüvelö Osztály mindössze három föből állt (Tarnóczy 2002: 283).

A teljesség kedvéért megemlítendő, hogy míg az MTA Nyelvtudományi Intézetéböl a nyelvmüvelés fokozatosan kiszorulni látszott, ebben az időszakban jöttek létre az MTA támogatásával a határon túli, nyelvmüvelési kérdésekkel is foglalkozó - az előző fejezetben bemutatott - magyar nyelvi irodák (pl. a Gramma Nyelvi Iroda Dunaszerdahelyen, a Szabó T. Attila Nyelvi Intézet Kolozsváron és Sepsiszentgyörgyön) (Balázs 2005: 301).

2003-ban Posgay Ildikó lett a Nyelvtudományi Intézet Nyelvmüvelő és Nyelvi Tanácsadó Osztályának vezetője (N. Fodor 2017: 508). Ekkoriban - három évre egy fiatal kutatóval kiegészülve - az osztály létszáma hét fő volt. Ennek az időszaknak az egyik fontos kutatása volt a kodifikált nyelvhasználati formákhoz kapcsolódó attitüdvizsgálat: azt a kérdést helyezték a középpontba, hogy a magyar anyanyelvi beszélők mennyire szabály- és normakövetők (Domonkosi 2007). Az osztály munkatársai rendszeresen szerveztek szakmai találkozókat a dunaszerdahelyi Gramma Nyelvi Irodával a nyelvmüvelés megújításáról, a nyelvi tervezésről, a nyelvi tanács- 
adás elméleti és gyakorlati problémáiról. Folytatódott a közönségszolgálati munka: a munkatársak nyelvi ismeretterjesztő rádió- és televíziómüsorokban vettek részt, cikkeket írtak az Édes Anyanyelvünk folyóiratba, a nyelvi tanácsadás keretében 394 szakvélemény készült. A telefonon érkező hívások és az elektronikus levelek száma 2006-ban megközelítette a 3000-et, illetve az 1500-at [35].

A 2000-es évek végén a Nyelvtudományi Intézet szervezetét illetően újabb változások történtek. A tanácsadó szolgálat kapacitása csökkent, ezért az intézeti szerkezeti változások következtében a Nyelvmüvelő Osztály 2010-ben egyesült a Nyelvtechnológiai, valamint az Élőnyelvi Osztállyal, amelyből 2013. január 1-jén létrejött a Nyelvtechnológiai és Alkalmazott Nyelvészeti Osztály (Váradi 2013), benne a Nyelvmüvelö és nyelvi tanácsadó kutatócsoport.

Ahogy a 3.8. pontban említettem, ebben az időszakban, 2006-ban alakult meg a korábban már bemutatott, hasonló szolgáltatásokat nyújtó Magyar Nyelvi Szolgáltató Iroda (MANYSZI) (Nagy 2010). „Az iroda ma is müködik, vállalkozási tevékenysége mellett ingyenes telefonos nyelvi gyorssegélyszolgálatot müködtet, pótolva a Magyar Tudományos Akadémia Nyelvtudományi Intézetében nemrég megszüntetett nyelvi tanácsadást" - olvashatjuk egy Magyar Nemzet-beli cikkben (Hanthy 2011), amely természetesen pontosításra szorul, hiszen az intézeti nyelvi tanácsadás nem szünt meg, csak az önálló osztály, amelynek keretében korábban müködött.

\subsection{A jelen}

Az egykori Nyelvmüvelő Osztály a feladatait jelenleg a Nyelvtechnológiai és Alkalmazott Nyelvészeti Osztály egyik kutatócsoportjaként, megújult lehetőségekkel és korszerü nyelvtechnológiai háttérrel végzi (Heltainé Nagy 2014). A kérdések megválaszolásában nagy segítséget jelentenek a különféle korpuszok, leginkább a mai magyar nyelv reprezentatív korpusza, a Magyar nemzeti szövegtár (OraveczVáradi-Sass 2014). A nagyközönség kedvelt eszköze a 2013-ban megnyílt online helyesírási tanácsadó portál, a helyesiras.mta.hu (Ludányi et al. 2014).

2019-ben a Nyelvmüvelö és nyelvi tanácsadó kutatócsoportnak egy teljes és három részmunkaidős dolgozója van. A munkatársak egyéni kutatásai az alkalmazott nyelvészet területeire irányulnak: nyelvmüvelés, helyesírás, névtan, stilisztika, szakmai (orvosi) nyelvhasználatok; nyelvi ideológiák, nyelv és iskola témakörökben.

A nyelvi tanácsadás legfőbb formája az e-mail, a levelek megválaszolása folyamatosan történik. Kedvelt az azonnali segítségnyújtást jelentő telefonos tanácsadás is (természetesen postai levélben is kérhető tanács, ez azonban manapság ritkaságszámba megy). A nyelvi tanácsadó szolgálat 2018-ban körülbelül 2000 e-mailben érkezett és több száz telefonos helyesírási, nyelvhasználati kérdésre adott választ. Az e-mailek száma 1084 db volt, egy e-mailben átlagosan két kérdést fogalmaztak meg az érdeklődők. A kérdezők köre - változatlanul - továbbra is sokszínü, megtalálható köztük a minisztériumi munkatárs, osztályvezető; médiamunkatárs, kiadói szerkesztő, projektmenedzser, szakfordító, termékmenedzser, orvos, tanár, iskolaigazgató, kutató, muzeológus, hallgatók, tanulók. Az intézmények közül többször kértek tanácsot - többek között - az MTA Kommunikációs Főosztályától, az Emberi 
Erőforrások Minisztériumától, az MVM Paksi Atomerőmü Zrt.-től és a Magyar Postától. A szolgálat 6 nyelvészeti szakvéleményt készített, és 26 darab közterületen elhelyezendő emléktábla nyelvi lektorálását végezte el önkormányzatok és magánszemélyek kérésére [36].

A tanácsadó szolgálat elmúlt éveinek leggyakoribb kérdéseiből és az azokra adott válaszokból a Nyelvtudományi Intézet honlapján olvasható egy válogatás [37], továbbá a helyesiras.mta.hu online tanácsadó portál Archívum menüpontjában is böngészhető a korábbi évek anyaga (az előzőhöz képest kevésbé kifejtett formában) [38].

Immár hat éve müködik a helyesiras.mta.hu portál, amely a helyesírási kérdésekben eligazodni vágyó nyelvhasználók körében nagy népszerüségnek örvend. Ugyanakkor azt is látni kell, hogy a portál webeszközei több okból sem képesek pótolni a „humán” nyelvi tanácsadást. Nem csupán azért, mert - főleg az idősebb korosztályban - létezik egy olyan réteg, amely nem aktív internethasználó, és szívesebben kér tanácsot telefonon, hanem azért is, mert a magyar helyesírás számos kérdése nem algoritmizálható, és így a portál sok helyesírási területen nem tud tanácsot adni (pl. a rövidítések, mozaikszók kérdései, bonyolultabb különírási-egybeírási kérdések, szaknyelvi helyesírási kérdések). Számos esetben több lehetséges írásmódot felajánl a portál, amelyek közül a felhasználónak kell kiválasztania az ő értelmezéséhez legközelebb állót, tapasztalataink szerint azonban ez gyakorta gondot okoz, ilyenkor a kérdezők telefonálnak vagy e-mailt írnak. Az a tendencia figyelhető meg, hogy a nyelvi tanácsadás régi és új módjai, eszközei egymás mellett élnek, kiegészítik egymást: ,a teljesen automatizált rendszer - szükség esetén - visszavezeti a kérdezőt az »emberhez«, a személyes nyelvi tanácsadáshoz” (Heltainé Nagy 2014).

Noha a tanácsadó szolgálathoz érkező kérdések 90/-a - igazodva az elmúlt hat évtizeden végigvonuló tendenciához - helyesírási jellegü, nem szabad megfeledkezni a maradék $\sim 10 \%$-ról, amelyek nem helyesírási jellegűek, és amelyek nem válaszolhatók meg automatikusan.

Mindebből tehát egyértelmüen következik, hogy „humán” nyelvi tanácsadásra a 2010-es évek végén is szükség van, és az elkövetkező évtizedekben is szükség lesz.

\subsection{A jövő: feladatok és lehetőségek}

Örvendetes, hogy a 2010-es években - a korszerü nyelvtechnológiai eszközöknek a tanácsadásba való bevonásával - elkezdődött a megújulás folyamata. A gyakorlati, technikai megújulás mellett fontos a nyelvi tanácsadás elméleti kérdéseinek, keretének tisztázása is. Tolcsvai Nagy Gábor (2017: 500) az ezredforduló egyik kiemelt nyelvstratégiai kérdésének tartja a nyelvi igazgatás (menedzsment) - amelyen ő elsősorban a nyelvi tanácsadást érti - szervezetének és nyelvtudományi hátterének a kialakítását. Ez az igény az intézeti nyelvi tanácsadás részéről már 2006-ban megfogalmazódott: az osztály éves beszámolójának célkitüzései között szerepelt a nyelvi menedzsment koncepciójának alkalmazása a tanácsadásban; a Nyelvmüvelő Osztály munkatársai a szlovákiai Gramma Nyelvi Irodával együttmüködve vizsgálták a nyelvi menedzsment problémáit és feladatait [35]. A nyelvmenedzselés- 
elmélet (Language Management Theory, LMT, Jernudd-Neustupný 1987) - átfogó jellegénél fogva - alkalmas elméleti keretnek tủnik a nyelvi tanácsadói munkához.

Ez az elmélet a nyelvi és kommunikációs problémák feltárására, elemzésére és kezelésére szolgál. Felfoghatjuk a nyelvtervezés-elmélet továbbfejlesztett változatának is, amelynek célja az előző hiányainak kiküszöbölése (Nekvapil 2006). Az utóbbi évtizedekben az elmélet a nemzetközi szakirodalomban egyre jelentősebbé vált, de a magyar nyelvészetben (egyelöre) kevésbé ismert, főként Lanstyák István és Szabómihály Gizella foglalkozik a témával (Szabómihály 2005, 2007; Lanstyák 2018). A nyelvi menedzselés során a (laikus) beszélők döntik el, mi tekinthető nyelvi problémának, nem pedig a nyelvészek, nyelvmüvelők. Ez a felfogás teljes mértékben összhangba hozható a nyelvi tanácsadás gyakorlatával, ahol a levélírók, telefonálók valós nyelvi problémáit ismerhetik meg a tanácsadók. Az elmélet átfogó jellegü, mivel mind a standard nyelvváltozat létrehozására irányuló nyelvi tervezést, mind a standard nyelvváltozat továbbfejlesztésére, differenciálására irányuló nyelvmüvelést is magában foglalja (Lanstyák 2014: 30). Az elmélet kurrens mivoltát mutatja, hogy a Cseh Tudományos Akadémia nyelvi tanácsadó központjának dolgozói a nyelvmenedzseléselmélet keretében végzik a munkájukat (Beneš et al. 2018; Dufek 2018).

Fontos feladat az intézeti nyelvi tanácsadás anyagának, a kérdéseknek és a válaszoknak módszeres, szisztematikus feldolgozása, ahogy az elmúlt évtizedekben időről időre sor is került erre. A feldolgozás célja kettős: 1) gyakorlati célú feldolgozás közérthető formában, a nagyközönségnek szóló nyelvi útmutató készítése (lehetőleg böngészhetô online adatbázis formájában); 2) egy tudományos kutatásokra alkalmas, strukturált adatbázisnak, a nyelvi tanácsadói diskurzusok korpuszának az elkészítése.

$\mathrm{Az}$ 1) pontban megfogalmazott cél részben megvalósult, mivel a 2007 utáni közönségszolgálati naplók válogatott anyaga (a kérdések és a válaszok) bárki által szabadon böngészhető adatbázis formájában felkerült a helyesiras.mta.hu portál Archívum menüpontjába [38]. Az adatbázis szabadszavas kereséssel, valamint kulcsszavak alapján kereshető. Az adatbázis 2013 óta nem frissült, így fontos feladat ennek az adatbázisnak a folyamatos karbantartása, bővítése.

A 2) pontban jelzett nyelvi tanácsadói korpusz elkészítése kiemelt jövőbeni feladatnak mutatkozik. Egy ilyen korpusznak a kérdések és a rá adott válaszok teljes szövegét változatlan formában kell tartalmaznia (természetesen anonimizált formában, az adatok érzékenységét maximálisan tiszteletben tartva), különféle jelenségekre, kulcsszavakra annotálva. Az annotációnak elsősorban a különféle nyelvi problémákra kellene kiterjednie: ehhez jó kiindulási alap lehet az a címkerendszer, amelyet ma is használnak a tanácsadó szolgálat munkatársai az e-mailek kategorizálásában, de egyéb annotáció is hasznos lenne, például - a nyelvi problémákkal szoros összefüggésben - a nyelvi ideológiáké (erről bővebben 1. Ludányi 2017, 2019). E korpusz reprezentatív képet adna a magyar beszélőközösségben tematizálódó nyelvi problémákról. De nem csupán ilyen típusú kutatások végzésére lenne alkalmas, hanem különféle népi nyelvészeti, pragmatikai, diskurzuselemzési stb. vizsgálatokra (a levelek teljes szövegének megörzése emiatt fontos).

Nem csupán az írott, hanem a beszélt nyelvi tanácsadói diskurzusok feldolgozására is szükség van. Hasonlóan a Cseh Nyelvi Intézet nyelvi tanácsadó 
központjának a munkájához (Beneš et al. 2018; Dufek 2018), célszerü lenne a telefonbeszélgetéseket rögzíteni, majd szoftveres segítséggel lejegyezni, végül az írott szövegekhez hasonlóan annotálni öket.

Felbecsülhetetlen értékü adatkincs, kordokumentum az a 66 darab közönségszolgálati napló, amelyből képet kaphatunk a Nyelvtudományi Intézet nyelvi tanácsadó szolgálatának több évtizedes müködéséről. E naplók anyagának átfogó feldolgozása még nem történt meg, noha kisebb intervallumok áttekintésére időröl idöre sort került, ahogy ezekre utaltam is a 4.1. fejezetben. Az utolsó naplók anyagának egy kisebb részének a feldolgozása a 2010-es évek elején megtörtént: a helyesiras.mta. hu portál Archívum menüpontjából szabadon elérhető a feldolgozott, kulcsszavakkal ellátott kérdésekből és válaszokból álló adatbázis [38]. A naplók digitalizálása, korszerü adathordozókra való mentése, archiválása is a fontos megvalósítandó feladatok közé tartozik. Távlati cél, hogy a megvalósítandó nyelvi tanácsadói korpusz idővel a 20. század anyagát is magában foglalja.

\section{5. Összefoglalás}

A nyelvi tanácsadás a szervezett nyelvi menedzselés és egyúttal a nyelvi ismeretterjesztés egyik kiemelten fontos válfaja, amely a hétköznapi beszélök részéröl folyamatosan fennálló igényt elégít ki. Hogy milyen fontos társadalmi igény a beszélök nyelvi kérdésekben való eligazítása, jól mutatja, hogy számos európai országban létezik ilyen szolgáltatás. Uhlířová (1997: 83) nyomán a nyelvi tanácsadás úgy is felfogható, mint a nyelvészek és a hétköznapi beszélők közti diskurzus, dialógus, ahol mindkét fél szerepe fontos, bár lényegesen különböző. A nyelvhasználók kérdeznek, a nyelvészek hivatalos nyelvi tanácsot, ajánlást adnak, a kérdezőktől pedig az az elvárt cselekvés, hogy megfogadják ezt. Ugyanakkor a nyelvészek maguk is információkat kapnak: a nagyközönségtől érkezett megkeresések az aktuális nyelvhasználatról, magukról a nyelvhasználókról, illetve az ő attitüdjeikről.

Magyarországon a nyelvi tanácsadás legrégebbi intézménye a Nyelvtudományi Intézet nyelvi tanácsadó szolgálata. A dolgozat második részében ennek az intézmények a tevékenységét ismertettem. A részletes történeti összefoglalóval célom részben a megemlékezés, a köszöntés is volt, mivel az Intézet 2019-ben ünnepelte fennállásának 70. évfordulóját. Az intézeti nyelvi tanácsadás múltjának és jelenének bemutatása mellett néhány javaslatot is felvázoltam, amely a nyelvi tanácsadó szolgálat megújulási folyamatának kiindulópontjául szolgálhat, és reményeim szerint szolgálni is fog.

\section{SZAKIRODALOM}

Andersson, Lars-Gunnar 2000. Language cultivation in Sweden. In: Sándor (szerk.): 85-98. Baksy Péter 2008. Nyelvi tervezés Norvégiában. In: Balázs-Dede (szerk.): 228-35.

Balázs Géza - Dede Éva (szerk.) 2008. Európai nyelvművelés. Inter Kht. - PRAE.HU, Budapest. 
Balázs Géza 2005. Nyelvi viták Kazinczytól Kazinczyig. Széphalom 15: 299-314.

Balázs Géza 2007. Grétsy László Magyar Örökség-díjas. Természet Világa 138/5: 196.

Beneš, Martin - Prošek, Martin - Smejkalová, Kamila - Štěpánová, Veronika 2018. Interaction between language users and a language consulting center: Challenges for language management theory research. In: Fairbrother-Nekvapil-Sloboda (eds.): 119-40.

Beszámoló $1960=$ [sz. n.] 1960. A pécsi nyelvművelő konferencia. Jelentés a konferenciáról. Magyar Nyelv 56: 148-51.

Bíró Ágnes - Tolcsvai Nagy Gábor (szerk.) 1985. Nyelvi divatok. Gondolat, Budapest.

Bíró Ágnes (szerk.) 1989. Szaknyelvi divatok. Gondolat, Budapest.

Bozsik Gabriella - Ludányi Zsófia (szerk.) 2019. Szabályzat, oktatás, gyakorlat. Helyesírásról sokszinüen. Líceum Kiadó, Eger.

Černá, Anna 2017. Jazykové poradenství jako zdroj lingvistických dat [Language consulting as a linguistic data source]. In: Orgoňová, Olga - Bohunická, Alena - Múcsková, Gabriela - Muziková, Katarína - Popovičová Sedláčková, Zuzana (eds.): Jazyk a jazykoveda v súvislostiach. Univerzita Komenského, Bratislava, 268-74.

Csernicskó István - Papp György - Péntek János - Szabómihály Gizella - Kiss Jenő 2005. A szomszédos országok magyar nyelvủ kutatóállomásairól. Magyar Nyelv 101: 105113.

Domínguez, Francesc - López, Núria 1995. Language International World Directory of Sociolinguistic and Language Planning Organizations. John Benjamins, Amsterdam/Philadelphia. https://doi.org/10.1075/liwd.1

Domonkosi Ágnes 2007. Attitűd, értékítélet, minősités: az értékszempont érvényesülése a nyelvi-nyelvhasználati reflexiókban. Acta Academiae Peadagogicae Agriensis. Nova Series Tom. XXXIV. Sectio Linguistica Hungarica, 38-54.

Domonkosi Ágnes - Lanstyák István - Posgay Ildikó (szerk.) 2007. Mühelytanulmányok a nyelvmüvelésröl. Gramma Nyelvi Iroda - Tinta Könyvkiadó, Dunaszerdahely-Budapest.

Dufek, Ondřej 2018. Language ideologies in Czech language counselling interactions. Elhangzott: 2nd International Conference on Sociolinguistics. Eötvös Loránd Tudományegyetem, Budapest, 2018. szeptember 7.

Eőry Vilma 1994. A kérdezők normatudata (nyelvművelő közönségszolgálati feladatok). In: Kemény-Kardos (szerk.): 177-181.

Fábián Pál 1970. Huszonöt év a nyelvmüvelésben. Magyar Nyelvőr 94: 261-70.

Fairbrother, Lisa - Nekvapil, Jiř́ - Sloboda, Marián (eds.): The Language Management Approach. A Focus on Research Methodology. Peter Lang, Berlin.

Ferenczy Géza - Ruzsiczky Éva (szerk.) 1964. Nyelvmüvelölevelek. Az Akadémia Nyelvtudományi Intézetének levelesládájából. Gondolat Kiadó, Budapest.

Földes Csaba 2008. A németországi nyelvi kultúra és nyelvmüvelés. In: Balázs-Dede (szerk.): 192-205.

Garvin, Paul L. 1993. Styles of codification. Brno Studies in English 20: 17-21.

Grétsy László 1961. Beszámoló a Nyelvművelő Bizottság 1960. november 2-i üléséről. Magyar Nyelvör 89: 411-2.

Grétsy László 1965. Tájékoztató a Nyelvmüvelő Munkabizottság 1965. március 3-i üléséről. Magyar Nyelvör 85: 411-2.

Grétsy László (szerk.) 1976. Mai magyar nyelvünk. Akadémiai Kiadó, Budapest.

Grétsy László (szerk.) 1976/1978. Hivatalos nyelvünk kézikönyve. Pénzügyminisztérium, Államigazgatási Szervezési Intézet. Budapest.

Gúti Erika - Varga Orsolya 2008. A németalföldi nyelvről. In: Balázs-Dede (szerk.): 220227.

Hanthy Kinga 2010. Jelentések a magyar nyelvről. Ütközőzónák. Magyar Nemzet, 2010. augusztus 7., 24. 
Havránek, Bohuslav 1932. Obecné zásady pro kulturu jazyka. In: Havránek, Bohuslav Weingart, Miloš (szerk.): Spisovná Feltina a jazyková kultura. Melantrich, Prague, 24558. Angolul: In: Rubin, Joan - Shuy, Roger W. 1973 (eds.): Language Planning: Current Issues and Research. Georgetown University Press, Washington, DC, 102-11.

Heltainé Nagy Erzsébet 2007. A nyelvmủvelés fogalma és terréniumai. In: DomonkosiLanstyák-Posgay (szerk.): 13-26.

Heltainé Nagy Erzsébet 2014. A nyelvi tanácsadás területei és újabb eszközei az MTA Nyelvtudományi Intézetében. Anyanyelv-pedagógia 7/1: http://www.anyanyelv-pedagogia.hu/ cikkek.php?id=505 (letöltve: 2016. 07. 27.)

Herman József 1988. Tájékoztató az MTA Nyelvtudományi Intézetének munkatervéröl. $M a-$ gyar Nyelv 84: 393-84.

Hírek 1954 = A Magyar Tudományos Akadémia Nyelvmüvelő Főbizottságának hírei. Magyar Nyelvör 78: 281-2.

Imre Samu 1973. A Nyelvtudományi Intézet középtávú (1972-1975.) tudományos kutatási terve. Magyar Nyelv 69: 15-20.

Jahr, Ernst Håkon 2000. On the use of dialects in Norway. In: Sándor (szerk.): 75-84.

Janich, Nina - Greule, Albrecht (Hrsg.) 2002. Sprachkulturen in Europa. Ein internationales Handbuch. Gunter Narr Verlag, Tübingen.

Jernudd, Björn 2018. Questions submitted to two language cultivation agencies in Sweden. Fairbrother-Nekvapil-Sloboda (eds.): 101-117.

Jernudd, Björn H. - Neustupný, Jiří Václav 1987. Language planning: for whom? In: Laforge, Lorne (ed.): Proceedings of the International Colloquium on Language Planning. Les Press de L'Université Laval, Québec, 69-84.

Kemény Gábor - Kardos Tamás (szerk.) 1994. A magyar nyelvi norma érvényesülése napjaink nyelvhasználatában. MTA Nyelvtudományi Intézete, Budapest.

Kemény Gábor (szerk.) 1992. Normatudat - nyelvi norma. MTA Nyelvtudományi Intézete, Budapest.

Kemény Gábor 1996. Hozzászólás: Nyelvi tervezés, nyelvi politika II. rész. Magyar Nyelvőr 120: $381-2$.

Kiss Lajos 2000. Nyelvtudományi Intézet. A Magyar Tudományos Akadémia kutatóintézetei, Magyar Tudományos Akadémia, Budapest.

Kiss Lajos 2001. A Nyelvtudományi Intézet fél évszázada (1949-1999). A Magyar Tudományos Akadémia Nyelvtudományi Intézete, Budapest.

Koródi József 1970. Anyanyelvünk közönségszolgálata. Magyar Nemzet, 1970. július 7., 9.

Kovalovszky Miklós 1977. Nyelvfejlödés, nyelvhelyesség. Akadémiai Kiadó, Budapest.

Laihonen, Petteri 2010. A finn nyelv korpusztervezése, korpuszpolitikája. Magyar Nyelvjárások 194-214.

Lanstyák István 2014. Nyelvalakitás és nyelvi ideológiák. Comenius Egyetem, Pozsony.

Lanstyák István 2018. Nyelvalakitás és nyelvi problémák. Fórum Kisebbségkutató Intézet Gramma Nyelvi Iroda, Somorja.

Lőrincze Lajos 1951. A Nyelvmüvelő Munkaközösség. Az MTA Nyelvtudományi Intézet Közleményei 2/5: 80-4.

Lőrincze Lajos 1962. Nyelvművelésünknek egy esztendeje (Elnöki beszámoló a Magyar Tudományos Akadémia Nyelvművelő Munkabizottságában az 1961. évi munkáról). Magyar Nyelvör 86: 129-43.

Lőrincze Lajos 1964. Leveles könyvünk elé. In: Ferenczy- Ruzsiczky (szerk.): I-XXVI.

Ludányi Zsófia 2017. Nyelvi ideológiák és napjaink nyelvhasználati kérdései a nyelvi tanácsadó szolgálat tükrében. Alkalmazott Nyelvészeti Közlemények 12/2: 32-48.

Ludányi Zsófia 2019. Nyelvi ideológiák és kvalitatív szövegelemzés a nyelvi tanácsadói diskurzusokban. In: Bölcskei Andrea - Heltai János Imre (szerk.): Nyelv, kultúra, identitás. 
Alkalmazott nyelvészeti kutatások a 21. századi információs térben. IV. Szociolingvisztika, névtan, nyelvtörténet. Akadémiai Kiadó, Budapest. https://mersz.hu/hivatkozas/ m715nyki4sznny 3 (2020. 07. 13.).

Ludányi Zsófia - Miháltz Márton - M. Pintér Tibor - Takács Dávid 2014. helyesiras.mta.hu Az intelligens helyesíró portál. In: Ladányi Mária - Vladár Zsuzsa - Hrenek Éva (szerk.): Nyelv - társadalom - kultúra. Interkulturális és multikulturális perspektívák II. MANYE - Tinta Könyvkiadó, Budapest, 800-6. (Elektronikus dokumentum.)

Maitz, Peter 2010. Sprachpflege als Mythenwerkstatt und Diskriminierungspraktik. Aptum. Zeitschrift für Sprachkritik und Sprachkultur 6/1:1-19. https://www.philhist.uni-augsburg. de/lehrstuehle/germanistik/sprachwissenschaft/Literatur_maitz/cikk34m-_Sprachpflegeals-Mythenwerkstatt_pdf(letöltve: 2019. 10. 12.).

Minya Károly 2005. Rendszerváltás - normaváltás. A magyar nyelvmüvelés története, elvei és vitái 1989-töl napjainkig. Tinta Könyvkiadó, Budapest.

Minya Károly 2008. Nyelvmüvelés Finnországban. In: Balázs-Dede (szerk.): 79-88.

Minya Károly 2019. Internetes támogatás a helyesírásban. 11 év - 20123 kérdés és válasz. In: Bozsik-Ludányi (szerk.): 247-54.

MTA Nyelvtudományi Intézet 1999. 50 éves a Magyar Tudományos Akadémia Nyelvtudományi Intézete. MTA Nyelvtudományi Intézet, Budapest.

Nekvapil, Jiř́ 2006. From Language Planning to Language Management. Sociolinguistica 20: 92-104. https://doi.org/10.1515/9783484604841.92

Nekvapil, Jiř́ 2008. Language Cultivation in Developement Context. In: Spolsky, Bernard Hult, Francis M. (eds.): Educational Linguistics. Blackwell Publishing, 251-65. https:// doi.org/10.1002/9780470694138.ch18

Nekvapil, Jiří 2009. The integrative potential of Language Management Theory. In: Nekvapil, Jiří - Sherman, Tamah (eds.): Language management in contact situations: Perspectives from three continents. Peter Lang, Frankfurt am Main.

N. Fodor János 2017. Posgay Ildikó 70 éves. Magyar Nyelv 113: 506-9. https://doi. org/10.18349/MagyarNyelv.2017.4.506

Nagy Levente 2010. Új intézmény a nyelvmüvelés szolgálatában. Magyar Nyelvi Szolgáltató Iroda, 2006-2007. Széphalom 17: 449-50.

Népszabadság 1982. = [sz. n.] A nyelvművelő közönségszolgálat. Népszabadság, 1982. április $16 ., 7$.

Omdal, Helge. 2000. Changes in the linguistic climate in Norway? In: Sándor (szerk.): $63-$ 74.

Oravecz, Csaba - Váradi, Tamás - Sass, Bálint 2014. The Hungarian Gigaword Corpus. In: Calzolari, Nicoletta - Choukri, Khalid - Declerck, Thierry - Loftsson, Hrafn - Maegaard, Bente - Mariani, Joseph - Moreno, Asuncion - Odijk, Jan - Piperidis, Stelios (eds.): Proceedings of Ninth International Conference on Language Resources and Evaluation (LREC 2014), 1719-23.

Péntek János 2008. Termini: magyar nyelvészeti kutatóállomások hálózata a Kárpát-medencében. Kisebbségkutatás 17/4: 594-5.

Péteri Vanda 2008. Nyelvmüvelés, nyelvi tervezés Svédországban. In: Balázs-Dede (szerk.): 311-318.

Riegel, Mareike 2007. Sprachberatung im Kontext von Sprachpflege und im Verhältnis zu Nachslagewerken. Unter besonderer Beachtung der Sprachberatungsstelle des Wissen Media Verlages. Inaugural-Dissertation zur Erlangung der Doktorwürde der Philologischen Fakultät der Albert-Ludwigs-Universität Freiburg i. Br.

Rácz Endre 1960. Anyanyelvi műveltségünk konferenciája. Magyar Nyelvőr 84: 3-15.

Ruzsiczky Éva 1961. Egy év a telefon mellett. Magyar Nyelvör 85: 170-84. 
Sadeniemi, Matti 1955. A Finn Akadémia Nyelvmüvelő Szolgálatának munkájáról. Magyar Nyelvör 79: 306-10.

Sándor Klára (szerk.) 2000. Issues on Language Cultivation. JGyF Kiadó, Szeged.

Sándor Klára 2002. Nyelvművelés nálunk és más nemzeteknél. Társadalomkutatás 20: 12149. https://doi.org/10.1556/Tarskut.20.2002.1-2.5

Szoták Szilvia 2009. Az Imre Samu Nyelvi Intézet. In: Lanstyák István - Menyhárt József Szabómihály Gizella (szerk.): Tanulmányok a kétnyelvüségről V. Gramma Nyelvi Iroda, Dunaszerdahely. 199-204.

Szabómihály Gizella 2005. Nyelvművelés - nyelvtervezés - nyelvi menedzselés. Fórum Társadalomtudományi Szemle 7/4: 67-75.

Szabómihály Gizella 2007. A nyelvi menedzselés lehetséges szerepe a magyar nyelvalakításban. In: Domonkosi-Lanstyák-Posgay (szerk.): 52-67.

Takács Judit 2019. A finn helyesírásról - magyar szemmel. In: Bozsik-Ludányi (szerk.): $283-8$.

Tarnóczy Mariann 2002. Magyar szaknyelv határainkon innen és túl. Összefoglaló a műhelyfórumról. Debreceni Szemle 10: 274-85.

[teknős] 1961. Nyelvőrök a telefonnál. Magyar Nemzet, 1961. augusztus 17., 4.

Tolcsvai Nagy Gábor 2017. Tervezés, (ön)értelmezés, fenntartás. A magyar nyelvstratégia lehetőségei és kötelességei. In: Tolcsvai Nagy Gábor (szerk.): A magyar nyelv jelene és jövője. Gondolat Kiadó, Budapest, 487-507.

Tompa József 1955. Közönségszolgálatunk müködéséröl. Az MTA Nyelvtudományi Intézet Közleményei 6/1: 103-9.

Tölgyesi Tamás 2008. A nyelvmüvelés helyzete Csehországban. In: Balázs-Dede (szerk.): $51-61$.

Uhlírová, Ludmila 1997. "Language service" is also a service for linguistics. Linguistica Pragensia 7: 82-90.

Váradi Tamás 2013. helyesírás.mta.hu. Helyesírási tanácsadó portál. Édes Anyanyelvünk 35/4: 17 .

Víghné Szabó 2008. Nyelvmúvelés Észtországban. In: Balázs-Dede (szerk.): 67-74.

Zajíc, Zbyněk - Psutka, Josef V. - Zajícová, Lucie - Müller, Luděk - Salajka, Petr 2019. Diarization of the Language Consulting Center Telephone Calls. In: Salah, Albert Ali-Karpov, Alexey - Potapova, Rodmonga (eds): Speech and Computer. SPECOM 2019. Springer, Cham, 549-58. https://doi.org/10.1007/978-3-030-26061-3_56

\section{INTERNETES HIVATKOZÁSOK}

[1] Institutet för språk och folkminnen [Svéd Nyelvi és Folklórintézet]. http://www. sprakochfolkminnen.se/om-oss/radgivning/sprakradgivning.html (2019. 07. 15.)

[2] Frågelådan [Kérdések adatbázisa]. http:/www.sprakochfolkminnen.se/sprak/ sprakradgivning/frageladan.html (2019. 08. 13.)

[3] Språkrådet [Nyelvi Tanács]. https://www.sprakochfolkminnen.se/om-oss/kontakt/ sprakradet.html (2019. 07. 15.)

[4] Norvég Nyelvi Tanács. https://www.sprakradet.no/sprakhjelp/ (2019. 08. 13.)

[5] Språkrådets seksjoner og ansatte [A nyelvi tanácsadás részlegei és dolgozói]. https://www. sprakradet.no/Vi-og-vart/Om-oss/Kontakt/Sprakradets-sekretariat (2019. 08. 13.)

[6] Har du eit språkspørsmål? [Kérdése van?]. https://www.sprakradet.no/sprakhjelp/ Skriverad/Spraksporsmal-Sprakradet (2019. 08. 13.)

[7] Svar på språkspørsmål [A kérdésekre adott válaszok]. https://www.sprakradet.no/ svardatabase (2019. 08. 13.) 
[8] Kielitoimiston ohjepankki [Nyelvi tanácsadó adatbank]. http://www. kielitoimistonohjepankki.fi (2019. 08. 13.)

[9] Telephone counselling [Telefonos tanácsadás].https://www.kotus.fi/en/services/telephone counselling (2019.08. 13.)

[10] Keelenõu läbi aja. http://keeleabi.eki.ee/?leht=6 [2019. 08. 13.)

[11] Keelekorraldajad [A nyelvi tanácsadás munkatársai]. http://keeleabi.eki.ee/?leht=2 (2019. 08. 13.)

[12] Keelenõuvakk [Nyelvi adatbázis]. http://keeleabi.eki.ee/?leht=4 (2019. 08. 13.)

[13] Taaladvies. Een antwoord op vele concrete vragen over taal en spelling [Nyelvi Tanács. Válasz sok konkrét nyelvi, helyesírási kérdésre]. https://taaladvies.net (2019. 08. 15.)

[14] Over Taaladvies [A Nyelvi Tanácsról]. https://taaladvies.net/taal/advies/verantwoording (2019. 08. 15.)

[15] Stel een taalvraag over het Nederlands [Kérdezzen a németalföldi nyelvröl]. https:// taaladvies.net/vraag (2019. 08. 15.)

[16] Het Genootschap Onze Taal [A Mi Nyelvünk Társaság]. https://onzetaal.nl/over-onzetaal (2019. 08. 13.)

[17] Spellingsite.nu. https://spellingsite.nu (2019. 08. 13.)

[18] Over de Taaladviesdienst [A nyelvi tanácsadó szolgálatról]. https://onzetaal.nl/taaladvies/ over-de-taaladviesdienst (2019. 08. 13.)

[19] Medewerkers [Dolgozók]. https://onzetaal.nl/over-onze-taal/organisatie/medewerkers (2019. 08. 13.)

[20) Vraag stellen [Tegyen fel kérdést]. https://onzetaal.nl/taaladvies/mailformulier (2019. 08. 13.)

[21] Taaltelefoon [Nyelvi telefon]. https://taaladvies.net/taal/advies/instanties/\#003 (2019. 08. 16.)

[22] Taaltelefoon [Nyelvi telefon]. https://www.taaltelefoon.be (2019. 08. 15.)

[23] Taaladvies - contact met de Taaltelefoon [Nyelvi tanácsadás - vegye fel a kapcsolatot a Taaltelefoonnal]. https://www.taaltelefoon.be/stel-uw-taalvraag (2019. 08. 16.)

[24] Das Leibniz-Institut für Deutsche Sprache. http://www1.ids-mannheim.de (2019. 08. 13.)

[25] Fragen und Antworten [Kérdések és válaszok]. https://gfds.de/category/fragen-undantworten (2019. 08. 13.)

[26] Sprachberatung [Nyelvi tanácsadás]. https://gfds.de/sprachberatung (2019. 08. 13.)

[27] Gutachten für das Standesamt [Szakvélemény az anyakönyvi hivatal részére]. https:// gfds.de/vornamen/gutachten-fuer-das-standesamt (2019. 08. 13.)

[28] Oddělení jazykové kultury [Nyelvmüvelő osztály]. http://www.ujc.cas.cz/o-ustavu/ oddeleni/oddeleni-jazykove-kultury/index.html (2019. 08. 21.)

[29] Internetová jazyková príručka [Internetes nyelvi útmutató]. http://prirucka.ujc.cas.cz (2019. 08. 21.)

[30] Magyar Nyelvi Szolgáltató Iroda - Szolgáltatások. http://www.e-nyelv.hu/szolgaltatasok (2019. 10. 01.)

[31] Szabályzat http://www.e-nyelv.hu/szabalyzat (2019. 10.01.)

[32] Nyelvi tanácsadás ürlapja. http://www.e-nyelv.hu/nyelvi-tanacsadas (2019. 10. 01.)

[33] A nyelvi tanácsadás adatbázisa. http://www.e-nyelv.hu/kategoria/nyelvi-tanacsadas (2019. 10. 01.)

[34] Termini magyar-magyar szótár. http://termini.nytud.hu/htonline (2019. 10. 01.)

[35] A Nyelvművelő és Nyelvi Tanácsadó Osztály 2006. évi beszámolója. http://www.nytud. hu/oszt/nyelvmuvelo/besz/besz2006.pdf (2019. 10. 01.) 
[36] A Nyelvtechnológiai és Alkalmazott Nyelvészeti Osztály jelentése a 2018. évről. http:// www.nytud.hu/oszt/korpusz/resources/nyt_alkny_jelentes2018.pdf (2019. 10. 01.)

[37] Gyakran ismétlődő kérdések. http://www.nytud.hu/oszt/nyelvmuvelo/gyik/index.html [2019. 08. 21.)

[38] Helyesiras.mta.hu - Archívum. https:/helyesiras.mta.hu/helyesiras/default/hqa (2019. 08. 21.)

\author{
Ludányi Zsófia \\ Eszterházy Károly Egyetem \\ Nyelvtudományi Intézet \\ https://orcid.org/0000-0002-8506-5684
}

\begin{abstract}
SUMMARY
Ludányi, Zsófia

\section{Language management and language counselling: Situation report, possibilities, and tasks}

The paper deals with language counselling, a type of organized language management, in the framework of Language Management Theory. The first part introduces institutions of language counselling in some European countries. Next, the situation in and around Hungary is presented in detail, including the work of institutions offering Hungarian language services in surrounding countries. The second part of the paper describes language counselling carried out in the Research Institute of Linguistics of the Hungarian Academy of Sciences: in addition to a summary of its past and present, some plans for the future are also sketched.

Keywords: Language Management Theory, organized language management, language counselling, language cultivation. 